\title{
Middle Cambrian trilobites from the Ekspedition Bræ Formation of North Greenland, with a reappraisal of the genus Elrathina
}

\author{
Gerd Geyer $^{1}$ and John S. Peel ${ }^{2}$ \\ ${ }^{1}$ Institut für Geographie und Geologie, Lehrstuhl für Geodynamik und Geomaterialforschung, Bayerische Julius-Maximilians-Universität \\ Würzburg, Am Hubland, 97074 Würzburg, Germany, 〈gerd.geyer@uni-wuerzburg.de〉 \\ ${ }^{2}$ Department of Earth Sciences (Palaeobiology), Uppsala University, Villavägen 16, SE-752 36 Uppsala, Sweden, 〈john.peel@pal.uu.se〉
}

\begin{abstract}
The richly fossiliferous Ekspedition Bræ Formation of North Greenland yields a typical oligospecific fossil assemblage with well-preserved trilobites, helcionelloids, and lingulate brachiopods. The trilobites include Itagnostus subhastatus new species, Itagnostus sp. cf. I. gaspensis (Rasetti, 1948), Elrathina aphrodite new species, Elrathina athena new species, Elrathina hera new species, and Elrathia groenlandica new species-a fossil assemblage typical of the Bathyuriscus-Elrathina Zone as known from the Cordilleran regions of Laurentia. Excellent preservation allows a detailed assessment of the prosopon and elucidates aspects of the ontogenetic development of Elrathina and Elrathia. An evaluation of Elrathina includes a redescription of its type species, E. cordillerae (Rominger, 1887), based on the type material, and indicates that most specimens collected from the Burgess Shale and previously dealt with as E. cordillerae represent a new species.
\end{abstract}

\section{Introduction}

Early geological exploration of the Laurentian margin in northern Greenland depended on dog-sledge expeditions under extreme climatic conditions. Lower and middle Cambrian faunas were first described by Poulsen (1927) on the basis of collections made by the Danish geologist and explorer Lauge Koch in North-West Greenland $\left(79^{\circ} \mathrm{N}, 70^{\circ} \mathrm{W}\right)$ during $1916-23$. Similar logistics were employed by J.C. Troelsen in the same area during 1939-41 (Poulsen, 1958, 1964), but it was not until helicopter-supported regional geological investigations by the Geological Survey of Greenland during 1978-1985 that the full spectrum of the Cambrian record in North Greenland, beyond $80^{\circ} \mathrm{N}$ and in the segment $35^{\circ}-55^{\circ} \mathrm{W}$, was revealed (Higgins et al., 1991; Ineson and Peel, 1997). In contrast with the mainly platform interior succession from North-West Greenland, fossiliferous lower-middle Cambrian outcrops in North Greenland are dominated by a transition from the platform margin to deep outer shelf deposits (Higgins et al., 1991; Ineson and Peel, 1997, 2011). Faunas ranging in age from Cambrian Series 2, Stage 4 to Series 3, Stage 7 (Guzhangian) have been documented (Peel 1988, 1994; Blaker and Peel, 1997; Geyer and Peel, 2011), although the oldest fauna is the Sirius Passet Lagerstätte (Cambrian Series 2, Stage 4; Ineson and Peel, 2011; Peel and Ineson, 2011a, b). The fauna of the Ekspedition Bræ Formation (Ineson and Peel, 1997; Fig. 1) has not been described in detail. Palmer and Peel (1979) discussed a faunal list and Peel and Streng (2015) proposed a new bradoriid arthropod. The material described below represents the oligospecific fossil assemblage typical of the formation, with well-preserved trilobites such as Itagnostus, Elrathina, and Elrathia, as well as helcionelloids and lingulate brachiopods. This assemblage is typical for a
Laurentian open-shelf fauna of the middle Cambrian upper Topazan and particularly lower Marjumian (uppermost Stage 5/lower Drumian) interval. The famous and well-studied members of the Stephen Formation in the Canadian cordillera (inclusive of the Burgess Shale) illustrate variability and differences in preservation of coeval faunas (e.g., Rasetti, 1951).

\section{Ekspedition Bræ Formation}

The Ekspedition Bræ Formation forms part of the northward prograding Brønlund Fjord Group and was deposited during a lowstand of sea level (Surlyk and Ineson, 1987; Higgins et al., 1991; Ineson and Peel, 1997). It was named after a small glacier flowing east into the head of J. P. Koch Fjord in Lauge Koch Land and crops out in southern Freuchen Land, Lauge Koch Land, and western Peary Land, North Greenland (Fig. 1). The formation consists mainly of pale-weathering, thin-bedded, dark-gray lime mudstones and skeletal wackestones, interbedded with gray-green calcareous mudstones that form distinctive recessive, grayweathering slopes between cliff-forming formations below and above (Ineson and Peel, 1997). It attains a thickness of $82 \mathrm{~m}$ at its type locality south of the snout of Ekspedition Bræ, but thins to the west and east, being only $30 \mathrm{~m}$ thick on the eastern side of J. P. Koch Fjord and in Løndal (Fig. 1). Despite the considerable thinning, the lithological composition remains constant, although the argillite content decreases to the south and increases to the west (Ineson and Peel, 1997).

Most of the available material was picked from the taluscovered outcrops. Preservation of the fossils is generally excellent, but usually affected by subrecent diagenesis and weathering. GGU sample 225501 (collected on 20 June 1979) consists of slabs of thin (several millimeters to $3 \mathrm{~cm}$ thick), 


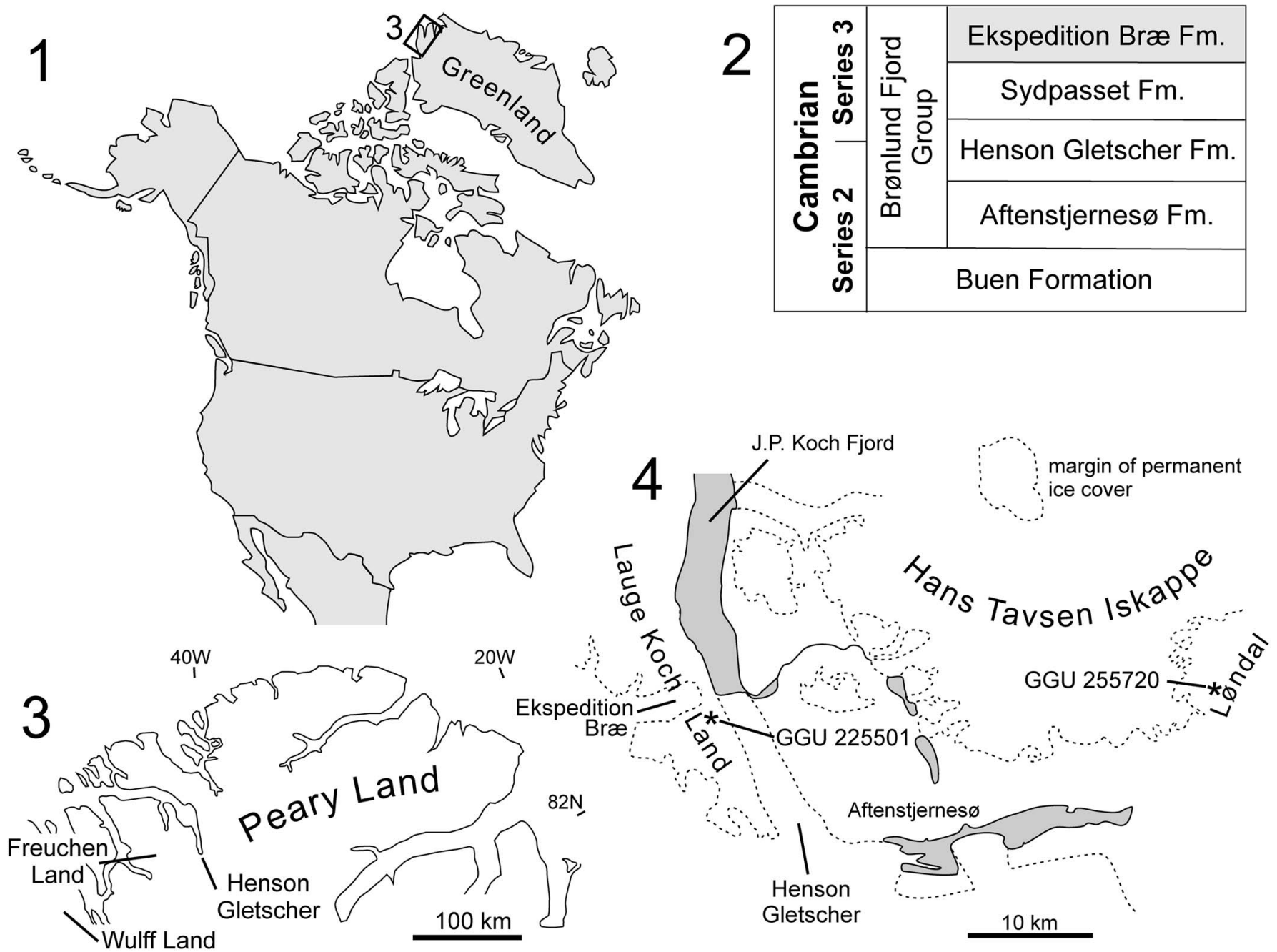

Figure 1. Geographical and geological setting of the Ekspedition Bræ Formation; (1) North America with the framed outcrop area in North Greenland (enlarged in Fig. 1.3); (2) Lithostratigraphical nomenclature of lower and lower middle Cambrian units (Cambrian Series 2 and part of Series 3) in North Greenland; (3) Sketch map of the Peary Land region showing the position of Freuchen Land and Henson Gletscher; (4) Henson Gletscher/J. P. Koch Fjord and Løndal areas showing sample localities (GGU 225501 and GGU 255720) of the Ekspedition Bræ Formation.

platy, dark-gray lime mudstone with occasional fossil shells or sclerites floating in the matrix without grain support. The planar surfaces are pale and often weathered to show the typical epikarstic rough exterior of rocks exposed for some time under arctic climate. The sample was collected from the middle part of the formation at its type section. GGU sample 225720 (collected on 16 July 1979) is very similar lithologically to GGU sample 225501, but from the western side of Løndal. The slabs are from talus lying on the surface of the formation and originate from the middle part of the formation.

\section{Correlation and biostratigraphy}

The trilobites preserved in the samples belong to only three genera and in total six species. All of the genera (Itagnostus, Elrathina, and Elrathia) are well known and widely distributed over Laurentia, whereas all of the species, perhaps except for Itagnostus sp. cf. I. gaspensis, are new. All three genera co-occur, for example, in the Pentagon Shale-Pagoda Limestone interval in northwestern Montana, U.S.A. (Deiss, 1939), and the presence of two of the genera in association has been noted from most well-known coeval middle Cambrian localities of Laurentian North America, such as Utah (Robison, 1964), Idaho (Resser, 1939), the Grand Canyon region (McKee and Resser, 1945), British Columbia (Rasetti, 1951), Pennsylvania (Rasetti, 1965), Georgia (Schwimmer, 1989), New York (Bird and Rasetti, 1968), and Alaska (Palmer, 1968).

Elrathina has been used as an index fossil for a medial middle Cambrian interval termed the Bathyuriscus-Elrathina Zone, and despite its unsettled synonymization with Ptychoparella and the discovery of one species of Elrathina in the distinctly older Albertella Zone (see Palmer, 1968; Palmer and Halley, 1979; and discussion under Elrathina below), this Itagnostus-ElrathinaElrathia assemblage indicates an interval widely correlatable within Laurentia in the upper part of the as yet unnamed Cambrian Stage 5. However, the occurrence of the assemblage in North Greenland is problematic in that it overlies strata that have been assigned to the Bolaspidella Zone, which generally overlies the BathyuriscusElrathina Zone. However, these zones appear to be partly coeval, and differences in the stratigraphic assignment can be explained by different biofacies. 
Palmer and Peel (1979) noted that the occurrence of the Ekspedition Bræ Formation fauna with Elrathina was problematic because a Bolaspidella fauna is present in stratigraphically older strata in North Greenland. This latter fauna occurs in the uppermost beds of the Henson Gletscher Formation in Lauge Koch Land and has been assigned to the Ptychagnostus gibbus Zone (Cambrian Stage 5) (Robison, 1988, 1994; Babcock, 1994; Blaker and Peel, 1997; Ineson and Peel, 1997). Palmer and Peel (1979) also recorded an apparent Bolaspidella Zone fauna of Peronopsis, Olenoides, Bolaspidella, Bathyuriscus, Elrathina, Ehmania, and Alokistocare from the base of the Ekspedition Bræ Formation at the head of Henson Gletscher (eastern side). Robison (in Peel and Streng, 2015) dated an equivalent horizon in Freuchen Land, about $35 \mathrm{~km}$ to the west, to the Ptychagnostus atavus Zone, which is the basal zone of the Drumian Stage (Cambrian Series 3, Stage 6). The latter zone is equivalent to the lower part of the Bolaspidella Zone (Babcock et al., 2007).

\section{Ecological aspects}

Macrofossils in the studied samples are typically concentrated on bedding planes. Leaching of calcareous beds from several horizons within the formation has produced insoluble residues of small shelly fossils (Peel and Streng, 2015). Articulated remains of trilobites form a high percentage of the species' remains in the samples (more than one-third for Itagnostus subhastatus n. sp., about two-thirds for Elrathina aphrodite n. sp., about four-fifths for Elrathina athena n. sp., slightly more than one-third for Elrathina hera n.sp., and only about 5\% for Elrathia groenlandica n. sp.). Most of the nearly complete exoskeletons lack librigenae and are thus carcasses that record the "olenid mode" of molting (e.g., Clarkson et al., 2003), in which the librigenae separate from the cranidium to release the trilobite through the thus-generated anterior opening, leaving a carcass of attached sclerites on the sea floor. Scattered isolated sclerites are sometimes vaguely accumulated into small clusters and then include fragmented remains; they may result from the activities of scavengers, which, however, are not recorded by body or trace fossils. However, isolated librigenae are rare in close proximity to the rest of the exuviae.

The studied samples record a low-diversity assemblage of comparable composition with six trilobite, two acrotretoid, and one helcionelloid species in the macrofossil record. The composition, based on 109 specimens, is illustrated in Figure 2 where the dominance of the three Elrathina and the single Elrathia species suggests their ecological fitness for the particular habitat conditions. In this respect, it should be emphasized that the unusual preservation and abundance of the well-known Elrathia kingii in the Wheeler Formation of the House Range, Utah, has been interpreted as result of an opportunistic ecological strategy for living in an exaerobic zone (Gaines and Droser, 2003). A similar, but probably less strongly restricted habitat may be assumed for the sample horizons of the Ekspedition Bræ Formation described herein, which may have forced the trilobites to similar strategies.

\section{Materials}

Repositories and institutional abbreviations.-The abbreviation GGU indicates collections from Greenland made under the auspices of Grønlands Geologiske Undersøgelse (Geological

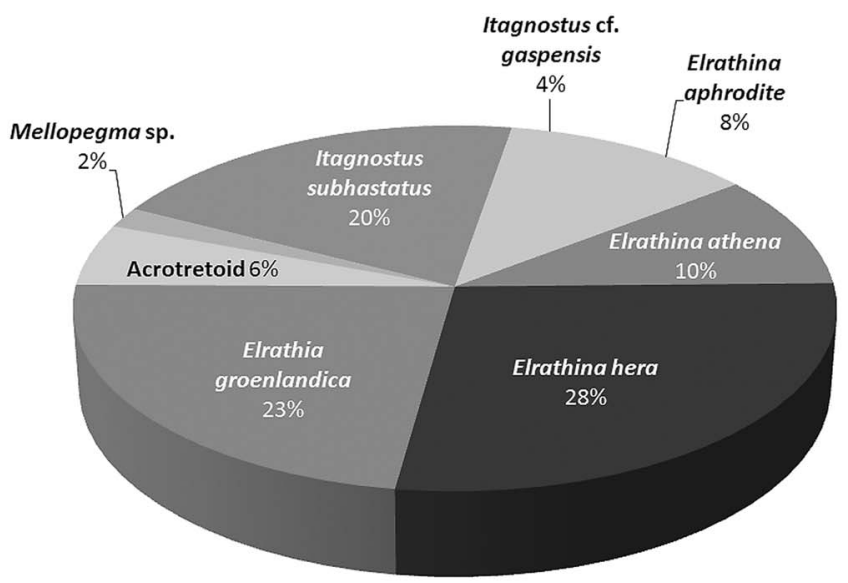

TOTAL FAUNA

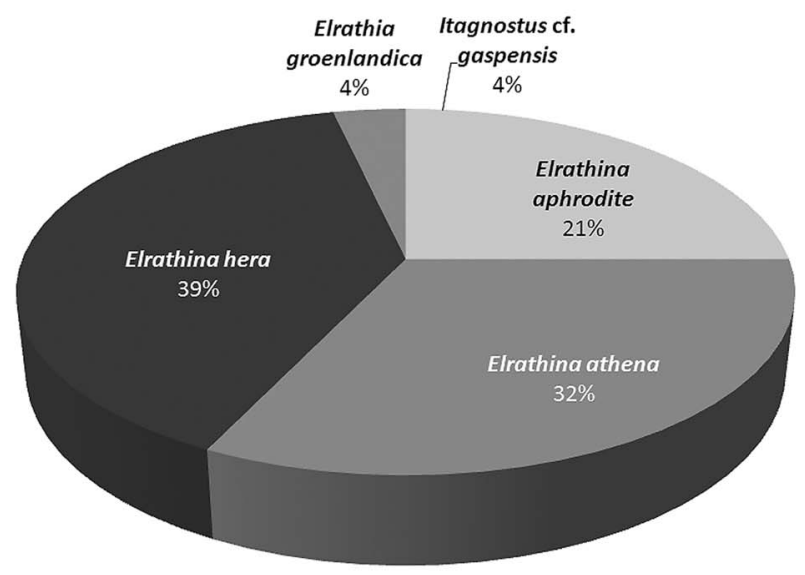

CARAPACES

Figure 2. Pie charts illustrating the composition of the studied ItagnostusElrathina fauna from the Ekspedition Bræ Formation. Composition of the entire fauna (top) and composition of the trilobite species for exoskeletons only (bottom).

Survey of Greenland, now a part of the Geological Survey of Denmark and Greenland). Individual type or figured specimens are identified by MGUH numbers and this material is deposited in the Geological Museum, Copenhagen, part of the Natural History Museum of Denmark. Additional figured material is housed in the Royal Ontario Museum (ROM), the University of Michigan Museum (UMMP), and the U.S. National Museum of Natural History (USNM) under the numbers given in the figure captions.

\section{Systematic paleontology}

Family Peronopsidae Westergård, 1936 Genus Itagnostus Öpik, 1979a

Type species.-Agnostus elkedrensis Etheridge, 1902; from the middle Cambrian of Australia and Siberia (by original designation).

Remarks.-The comprehensive reappraisal of the Peronopsis clade by Naimark (2012) clarified a number of problems within the complex evolutionary group and demonstrated evolutionary pathways, but also illustrated deficiencies in the knowledge of morphology and the difficulties in the correct weighting of 
characters. These problems particularly affect the Genus Itagnostus, which was introduced by Öpik (1979a, b) as a subgenus of Peronopsis Hawle and Corda, 1847. Laurie (2004) raised Itagnostus to generic level, dramatically emending the concept and diagnosis, and placing the genus within the family Spinagnostidae and subfamily Doryagnostinae. Naimark (2012) amply discussed the case and re-emended the genus. In addition, she discussed in detail problems resulting from both the inclusion of species such as Peronopsis interstricta (White, 1874), and the unstable concept of Itagnostus in respect to its phylogenetic relationship with Euagnostus Whitehouse, 1936.

We follow herein the general concept of Itagnostus sensu Naimark (2012) and suggest that Peronopsis interstricta should be placed within Naimark's morphogroup XIVa, under Itagnostus. The new species described below is similar to I. interstrictus, which has slightly larger pygidial spines. This character reinforces the placement among the species of Itagnostus, although I. interstricta can be regarded as a transitional species between Peronopsis (Svenax) Öpik, 1979a, b and Itagnostus.

Together with a number of other species of the Peronopsidae, species of Itagnostus have a median postaxial furrow on the pygidium. Kobayashi (1939) erected the genus Acadagnostus for such species, which Westergård (1946) subsequently placed in Peronopsis. As explained by Shergold and Laurie (1997), and in detail by Naimark (2012), Acadagnostus (type species: A. acadicus [Hartt in Dawson, 1868] [not "acadica" as used in some publications such as Naimark, 2012]) is a valid genus, which is taxonomically distinguished from Itagnostus.

Itagnostus subhastatus new species

Figure 3.1-3.7, 3.8?, 3.9?, 3.12, 3.13

Holotype.-MGUH 30893 (Fig. 3.3). Western side of Henson Gletscher, Lauge Koch Land, North Greenland, middle part of the Ekspedition Bræ Formation, GGU sample 225501.

Paratypes.-Western side of Henson Gletscher, Lauge Koch Land, GGU sample 225501: five fairly complete exoskeletons (figured specimens under MGUH 30903 and 30892), three cephala with attached thoracic segments (MGUH 30896, 30897, 30895); western side of Løndal, GGU sample 255720: one fairly complete carapace (under MGUH 30891), four cephala (figured specimen under MGUH 30894), two pygidia (figured specimen under MGUH 30902). Tentatively assigned to I. subhastatus: GGU sample 255720: two pygidia (MGUH 30899 and MGUH 30901).

Diagnosis. - Species of Itagnostus with a comparatively slender posterior glabellar lobe; anterior lobe of the glabella completely defined by furrow; preglabellar furrow absent; pygidial rhachis narrow, subtriangular to hastate, subacute posteriorly, with laterally developed transaxial furrows; postaxial furrow developed; small to rudimentary spines on the pygidial border; doublure comparatively wide.

Description.-Cephalon moderately convex, subcircular to subquadrate, with distinctly curved lateral margins and wellrounded anterior angles; length/width ratio $\sim 0.9$. Glabella bilobate, tapering forward. Posterior lobe with length about equal to width, slightly longer than 1.5 times length of anterior lobe, highest elevation about one-third from well-rounded posterior end; without tubercle or with extremely faint, narrow longitudinal node (Fig. 3.3). Anterior lobe evenly rounded in front. Transverse furrow straight. Anterior lobe well defined by moderately deep dorsal furrow. Occipital ring very narrow, continuous with the simple, triangular, slightly inequilateral basal lobes, which are somewhat oblique to axis.

Genae convex, preglabellar median furrow absent. Border moderately convex, growing in width from genal angles anteriorly, but subequal in width anteriorly between anterolateral corners; posterolateral corners with well-developed, highly raised thorn-shaped spines. Border furrow narrow, rather deep posterolaterally, moderately deep anteriorly.

Thorax of two segments. Axial rings laterally tripartite, strongly oblique furrow demarcates raised, oblique lateral nodes, which are smaller on anterior than on posterior segment. Axial furrow chevron shaped along axial rings. Pleurae on anterior segment a subangular bulb traversed by a shallow pleural furrow that curves strongly forward to demarcate a swollen subcircular anterior pleural band; with a small node-like thorn in a posterolateral position (Fig. 3.2); stout pleural tip strongly ventrally deflected. Pleurae on posterior segment short, but distinctly longer than in anterior segment, ventrally deflected and with obliquely forwarddirected, acute pleural tip; pleural furrow slightly s-shaped, anterior to midline of pleura, swinging anteriorly in distal portion; with fairly well-developed socket on posterior pleural band close to axial furrow (Fig. 3.3).

Pygidium moderately convex, subcircular to subquadrate, with weakly curved lateral and distinctly curved posterior margins; length/width ratio $\sim 0.85$. Rhachis variably of $68-77 \%$ pygidial length, $41-45 \%$ pygidial maximum width across anterior segment, which is defined by a broad constriction and a faint and wide depression instead of a distinct lateral furrow; lateral axial furrows obscure; posterior two-thirds or almost three-fourths of rhachis hastate in dorsal view, with variably developed and slightly broadened M3, narrowing into a pointed tip; median tubercle elliptical in outline, approximately one-third from anterior end.

Postaxial median furrow present, slit-like or developed as a triangular, posteriorly broadened depression (Fig. 3.3) that joins the dorsal and marginal furrows. Pleural lobes moderately convex. Border moderately convex, growing in breadth from anterolateral corners to a maximum of approximately twice this breadth on sagittal line; wider than on the cephalon; with somewhat variably developed, small and short marginal spines located slightly posterior to a transverse line drawn at tip of axis. Anterior border confluent with lateral border at distinct anterolateral corners, swinging forward and raised while slightly growing in width up to well-developed fulcral points that fit into sockets of posterior thoracic segment. Border furrow well developed, moderately deep, subequal in width throughout. Doublure slightly wider than border.

Lengths of cranidia in the present material $2.3-3.7 \mathrm{~mm}$; lengths of pygidia $1.6-3.5 \mathrm{~mm}$. Entire surface of carapace smooth.

Etymology.-From the Latin hastatus, lance-shaped; an allusion to the shape of the pygidial rhachis. 

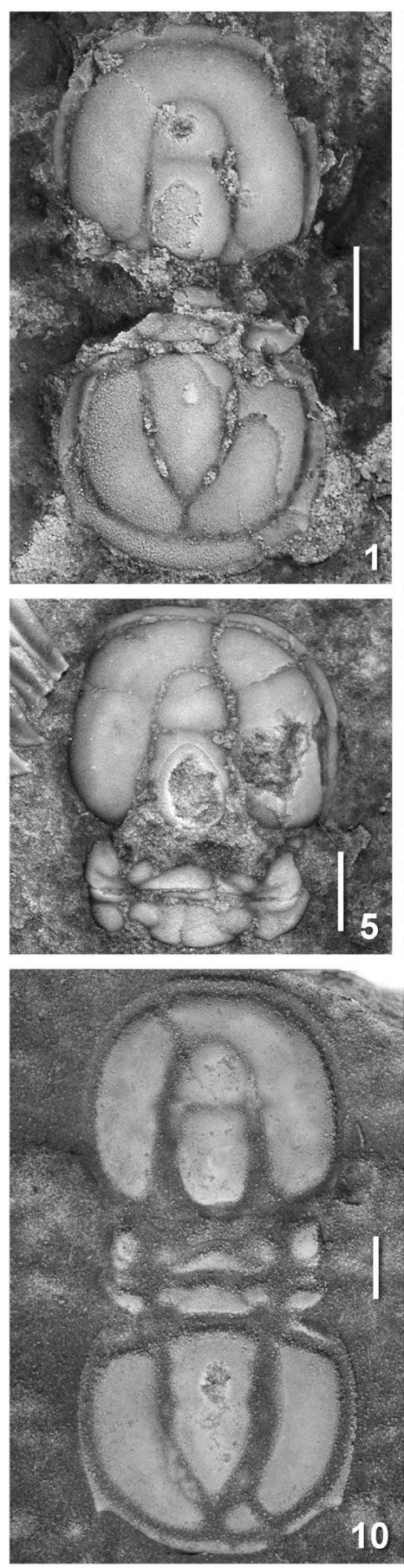
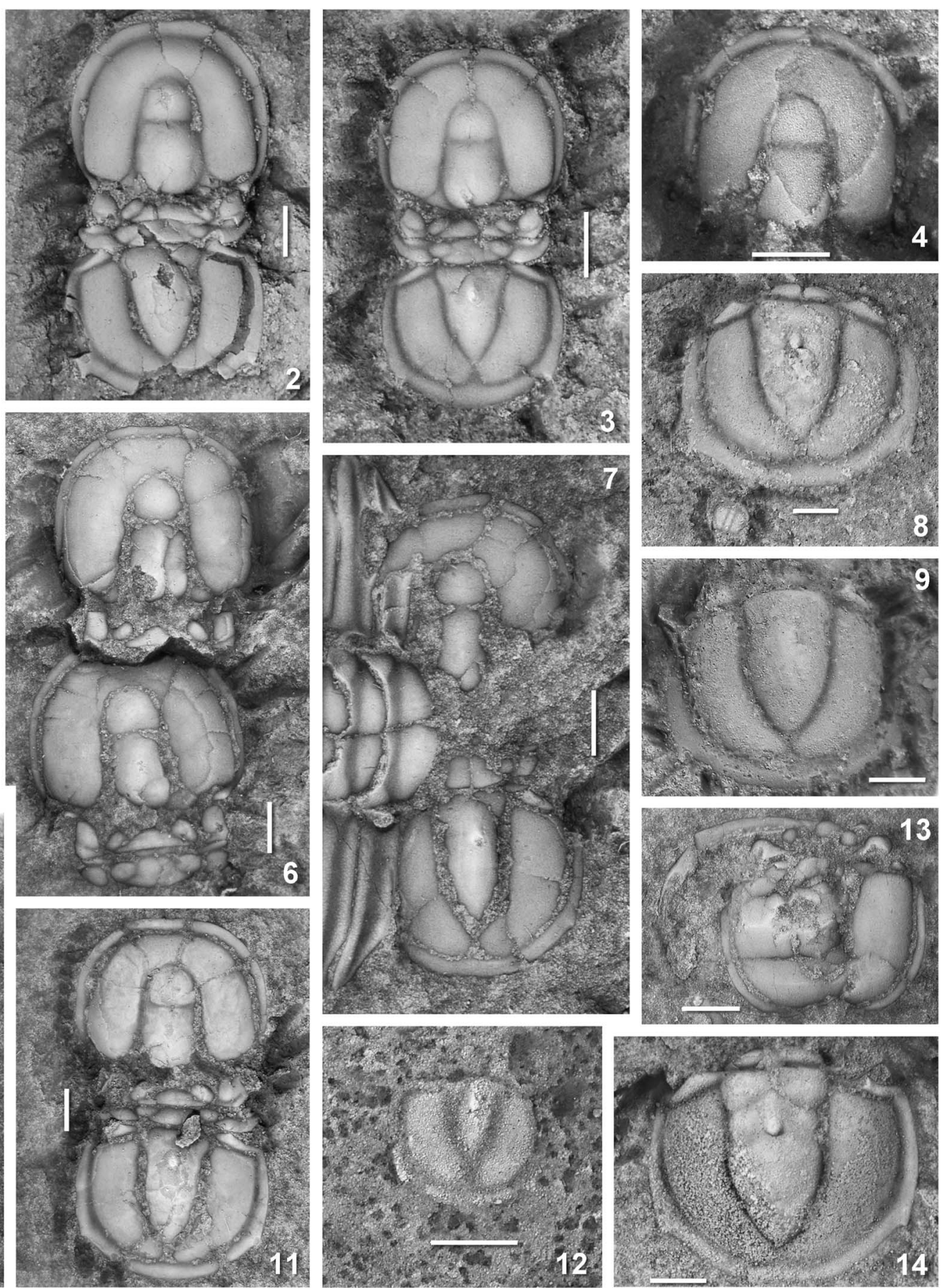

Figure 3. (1-7, 8?, 9?, 12, 13) Itagnostus subhastatus n. sp.; (1) Paratype, MGUH 30891, fairly complete, disarticulated carapace; (2) paratype, MGUH 30892, carapace; (3) holotype, MGUH 30893, carapace; (4) paratype, MGUH 30894, cephalon; (5) paratype, MGUH 30895, cephalon with articulated thorax; (6) paratype, MGUH 30896 and 30897, two cephala with articulated thorax; (7) paratype, MGUH 30898, disarticulated carapace, laterally covered by thorax of Elrathia groenlandica n. sp.; (8) MGUH 30899, pygidium tentatively assigned to I. subhastatus n. sp., with meraspid cephalon tentatively assigned to Elrathina hera n. sp., MGUH 30900; (9) MGUH 30901, pygidium tentatively assigned to I. subhastatus n. sp.; (12) paratype, MGUH 30902, pygidium of immature individual, internal mold; (13) paratype, MGUH 30903, distorted remains of an enrolled carapace; (10, 11, 14) Itagnostus sp. cf. I. gaspensis (Rasetti, 1948); (10) MGUH 30904, carapace, strongly recrystallized; (11) MGUH 30905, carapace; (14) MGUH 30906, pygidium. Dorsal views if not stated otherwise. Scale bars $=1 \mathrm{~mm}$.

Remarks.-Itagnostus subhastatus $\mathrm{n}$. sp. is closely related to the well-known species Itagnostus interstrictus (White, 1874), which is primarily distributed in the Bathyuriscus fimbriatus and Bolaspidella contracta subzones of the Bolaspidella Zone of Utah (Robison, 1964). Subsequently, I. interstrictus was described from the $P$. atavus Zone of Alaska and the
Ptychagnostus punctuosus Zone in the Cow Head Group, Newfoundland, with material assigned to the species from the Tomagnostus fissus and Liostracus allachjunensis zones of the Lena River basin, Siberia (Palmer, 1968; Egorova et al., 1982; Young and Ludvigsen, 1989; Westrop et al., 1996). Itagnostus subhastatus is distinguished from I. interstrictus, however, by a 
set of minor differences that particularly include the slightly more slender posterior glabellar lobe; differences in the morphology of the thoracic segments; a narrower and distinctly more pointed pygidial axis; smaller and almost rudimentary spines on the pygidial border; and a wider doublure (compare Robison 1964, pl. 82, figs. 1-15, 18).

Other similar species include Peronopsis (P.) scutalis (Salter in Hicks, 1872) from Scandinavia, $P$. (Svenax) egenus (Resser and Endo, 1937) from Manchuria, and Quadragnostus columbiensis (Rasetti, 1951) from the Bathyuriscus-Elrathina Zone of the Canadian Rockies. Peronopsis $(P$.) scutalis and $P$. (S.) egenus are best distinguished by posterolateral thickenings on the pygidial border, which appear similar to short spines. In addition to the absence of distinct spines on the border, they are differentiated by a decidedly thickened pygidial border, a more strongly extended posterior glabellar lobe, and in a narrowly incised cephalic border furrow. By contrast, $P$. columbiensis has a slightly bent transglabellar furrow, small basal lobes, marginal structures in the relatively narrow pygidial rhachis, and short postaxial space. Itagnostus subhastatus is furthermore distinguished from these species by the more hastate shape of its pygidial rhachis, more subcircular cephala and pygidia, and a relatively longer glabella. It should be noted that the studied material from the Ekspedition Bræ Formation is preserved in full relief or almost full relief, whereas material of the Siberian and Manchurian species is often flattened. These differences in the preservation, however, do not affect the discussed differences.

Itagnostus sp. cf. I. gaspensis (Rasetti, 1948) Figure 3.10, 3.11, 3.14

Description.-Cephalon subcircular to subquadrate, with distinctly curved lateral margins, anterior margin tends to have an almost straight median section; length/width ratio $\sim 0.85$. Posterior lobe of glabella with weakly curved sides, greatest slightly behind midlength, with width $\sim 85 \%$ length, slightly longer than 1.5 times length of anterior lobe, highest elevation about one-third from wellrounded posterior end; without faint, narrow longitudinal node. Anterior lobe evenly rounded or with slightly narrower curvature in front. Occipital ring very narrow, continuous with the simple, triangular, slightly inequilateral basal lobes.

Border growing in width from genal angles anteriorly, but subequal in width anteriorly between anterolateral corners.

Thoracic axial rings laterally tripartite, strongly oblique furrow demarcates raised, oblique lateral nodes, which are subequal in size on anterior as on posterior segment. Pleurae on anterior segment consist of a bulb-like anterior pleural band defined by a wellmarked shallow pleural furrow that curves strongly forward and fades close to the arcuate pleural tips (Fig. 3.11); posterior pleural band on anterior segment with narrow and low proximal and elevated and slightly broader, obliquely forward directed distal portions. Pleurae on posterior segment distinctly longer than in anterior segment, ventrally deflected, with obliquely forwarddirected, acute pleural tip; with socket on posterior pleural band close to axial furrow (Fig. 3.11).

Pygidium subsemicircular to subquadrate, with weakly curved lateral and distinctly curved posterior margins; length/ width ratio $\sim 0.80-0.85(\mathrm{~N}=4)$. Rhachis of $75-82 \%$ pygidial length, 40-43\% pygidial maximum width across anterior segment, which is defined by a distinct constriction and a shallow, but well-marked pair of lateral furrows, the branches of which curve forward from the axial furrows and demarcate bulb-like swellings of the first segment of the rhachis; second pair of axial furrows obscure; posterior two-thirds of rhachis ogival in dorsal view, with slightly broadened M3, narrowing into a pointed tip; median tubercle a longitudinal crest, most prominent point close to posterior end (Fig. 3.14). Postaxial median furrow developed as posteriorly broadened depression.

Lengths of cranidia in the present material $2.7-3.7 \mathrm{~mm}$, lengths of pygidia $3.2-4.2 \mathrm{~mm}$. Entire surface of carapace smooth.

Materials.-Western side of Henson Gletscher, Lauge Koch Land, North Greenland, GGU sample 225501: two fairly complete exoskeletons (under MGUH 30904 and 30905); western side of Løndal, North Greenland, GGU sample 255720: single pygidium (MGUH 30906). Material tentatively assigned to Itagnostus sp. cf. I. gaspensis: GGU sample 255720: two cephala.

Remarks.-The material treated here resembles the type material of Itagnostus gaspensis (Rasetti, 1948) from middle Cambrian limestone boulders within the so-called Lévis Conglomerate at Grosses Roches, Quebec. Differences exist in the slightly narrower glabella, the more tapering and slightly longer pygidial rhachis, the narrower pygidial border, and an apparently broader (sag.) articulating half-ring. Unfortunately, Rasetti (1948, pl. 45, figs. 1-3) figured only one cephalon and two pygidia. At least the pygidium assigned by Rasetti (1948, pl. 45, fig. 5) is not closely related to the species and belongs to a different genus in the concept of Naimark (2012).

A similar species, Peronopsis taitzuhoensis Lu, 1957 was described from the middle Cambrian Tangshih Formation (abandoned, now Hsuchuang Formation) and thus HsuchuangiaRuichengella through Bailiella-Lioparia zones of the Taizihe (earlier spelled "Taitzuhe") Valley, Benxi, Liaoning Province, and from the Henan Province (Lu, 1957; Lu et al., 1965; Pei, 1991). This species has been regarded as a subspecies of Itagnostus gaspensis by Naimark (2012), but we regard it as an independent, although closely related species within Itagnostus. Itagnostus sp. cf. I. gaspensis from Greenland differs from this species from South China in having a cephalon with an almost straight median sector of the anterior margin rather than being well rounded. In addition, the pygidial rachis is generally narrower and particularly in the posterior portion clearly narrower and more strongly tapering with less clearly impressed lateral furrows; the marginal spines are distinctly smaller. A similar form was described as Peronopsis sp. cf. I. taitzuhoensis from the Heicigou Group of the North Qilian District, Tarim Platform, Northwest China (Zhou and Dean, 1996).

The material of Itagnostus sp. cf. I. gaspensis from the Ekspedition Bræ Formation clearly differs from I. subhastatus n. sp., which appears in the same samples, in a number of characters: a shorter and nearly subparallel rather than tapering glabella with a relatively longer posterior lobe; a narrower anterior and lateral cephalic border; a distinctly longer pygidial rhachis with an ogival rather than hastate posterior portion and two constrictions as well as a longitudinal, crest-like median tubercle; a short depression connecting dorsal and border 
furrows; a less strongly broadening border; and marginal spines that are short and thorn-like.

Itagnostus interstrictus (White, 1874) has a posteriorly broadened posterior lobe and thus a clearly tapering glabella. Naimark (2012) assigned specimens from the Malokuonamka "Horizon" of the Siberian Platform described as Peronopsis aff. gaspensis (Egorova et al., 1982, pl. 51, figs. 1, 3) to Itagnostus interstrictus. Specimens described as Euagnostus aff. interstrictus by Laurie $(2004$, p. 245 , figs. $18 \mathrm{~A}-18 \mathrm{~N})$, however, were assigned by Naimark (2012) to I. gaspensis. Laurie (2004) stated that they differ from Itagnostus interstrictus only by having a posteriorly displaced glabellar tubercle; this was interpreted by Naimark (2012) as being a characteristic feature of I. gaspensis. The present specimens from the Ekspedition Bræ Formation are not well enough preserved to permit an unequivocal assessment based on this character; they appear to show a faint tubercle in a more central position on the posterior glabellar lobe and thus to indicate another character difference from I. gaspensis.

The similar species Peronopsis (P.) scutalis (Salter in Hicks, 1872) from Scandinavia (typical specimens figured by Westergård, 1946) lacks true pygidial spines. It is also very similar to Acadagnostus acadica (Hartt, 1868), from which it can be separated by the same character.

\section{Order Ptychoparioidea Swinnerton, 1915 \\ Superfamily Ptychopariacea Matthew, 1887 Family uncertain}

Remarks.-The subdivision of the Ptychopariacea is a major problem of trilobite taxonomy caused by at least three different issues. The generic concepts of numerous genera are far from settled, leading to frequent synonymization based partly on attempts to circumvent long-introduced, but insufficiently known species in the absence of basic restudy (see discussion below under Elrathina). Older descriptions of early middle Cambrian ptychoparioids from Laurentia are frequently based on incompletely known or even undeterminable material (e.g., Antagmus Resser, 1936; see Sundberg, 2007). The pygidial morphology is rarely given adequate notice. Ptychoparia Hawle and Corda, 1847 is a somewhat derived ptychopariacean so that its earlier use as a paradigmatic ptychoparioid is misleading and has lead to the introduction of confusing taxa above the genus level. Notoriously difficult ptychoparioid clades such as the Alokistocaridae or the Ptychopariidae are in urgent need of a rigorous approach to the analysis of morphological characters to unravel the relationships of taxa. Thus, even serious attempts to provide robust systematic groupings based on careful cladistics analyses (Sundberg, 1999, 2004; Esteve et al., 2012) must await a much more comprehensive database. Accordingly, we are unable to provide a confident placement for Elrathina and Elrathia at this time.

\section{Genus Elrathina Resser, 1937b}

Type species.-Conocephalites cordillerae Rominger, 1887; Stephen Formation, British Columbia, Canada (by original designation).

Remarks.-Recent investigations on the ptychoparioids from the Henson Gletscher Formation (Geyer and Peel, 2011) indicated that the comprehensive synonymization of a number of mono- and paucispecific ptychoparioid genera proposed by Blaker and Peel (1997, p. 123, 124) cannot be maintained. The suggested synonymy was based on apparent considerable morphological variation seen in cephala of many early and mid middle Cambrian assemblages of similar, generalized morphologies within genera such as Ptychoparella Poulsen, 1927, Syspacephalus Resser, 1936, Elrathina Resser, 1937b, and Eoptychoparia Rasetti, 1955. Blaker and Peel's (1997) suggestion to use Ptychoparella Poulsen, 1927 as an umbrella for multisegmented trilobites with a slightly tapering glabella, small palpebral lobes, a small, poorly segmented pygidium lacking particularly eye-catching characters was based merely on this taxon being the first described of the genera under discussion. This was an unfortunate choice, however, on account of the imperfect preservation of its type species-a situation that prompted Rasetti (1951) and Poulsen (1964) to propose restriction of the name to the type lot and with which we concur. Nevertheless, the synonymization has been accepted by a number of authors (e.g., Sundberg, 1999; Fletcher and Collins, 2003; Babcock et al., 2007; Robison and Babcock, 2011; Zhao et al., 2011). An earlier synonymization of Elrathina and Syspacephalus (Robison, 1976; Babcock, 1994) obviously had the same motivation of a growing mosaic of characters that appeared to bracket morphological distances between previously introduced genotypes.

The uncertainty does not result solely from deficiencies in preservation and incomplete knowledge of characters of the species concerned, but also from difficulties in weighting the characters to be used to unravel phylogenetic pathways. Furthermore, there is an obvious plethora of ptychoparioid species present in the older two-thirds of the middle Cambrian. The problems that result from regarding such a large number species as cogeneric with Ptychoparella brevicauda Poulsen, 1927 are somewhat surprising. Ptychoparella brevicauda is known only from three imperfectly preserved specimens: a cranidium with most of the occipital ring broken off; a partial librigena; and a pygidium with damaged right-hand side. The cranidium has a quite strongly tapering glabella with almost straight sides and three pairs of lateral glabellar furrows. Its preglabellar field is of about the same sagittal breadth as the anterior border, which lacks any sign of a median swelling; and it shows small palpebral lobes in a conspicuously posterior position. In contrast, the librigena shows an ocular suture that is larger than the corresponding palpebral lobes of the cranidium and in a more anterior position so that the librigena most probably does not belong to an individual of the same species. Finally, the pygidium is lenticular with segmented rhachis and pleurae. Thus most of the species described under Elrathina are clearly distinguished and cannot be accomodated within Ptychoparella. The same is true for Syspacephalus and Eoptychoparia.

Elrathina is one of the genera with a fairly generalized morphology, and since Resser's (1937b) rudimentary introduction and the rapid emendation by Deiss (1939), it has grown into one of the frequent taxonomic waste baskets among the Alokistocaridae, with at least 23 validly described species, or subspecies. The difficulties that result from the attempt to perfectly characterize the species' morphology when based on imperfectly preserved material have been addressed by Rasetti (1951, p. 221) in a surprisingly plain style. 
The type species, Elrathina cordillerae, was introduced as Conocephalites cordillerae by Rominger (1887) and shown in a single figure (Rominger 1887, pl. 1, fig. 7), which provides an utterly erroneous impression of its morphology; it is discussed below. Its bilobate terminal axial piece in the pygidium could even be used as a criterion to separate it from the vast majority of species assigned to Elrathina. However, as long as the morphologic plasticity of this character is not fully understood, we suggest retention of the traditional generic concept.

Examination of the species assigned to Elrathina and species assigned to similar, closely related genera suggests that diagnostic characters of the genus must include: (1) the shape of the glabella with subparallel sides or slightly tapering forward; (2) the pattern of three to four pairs of shallow lateral glabellar furrows, S1 with a long and strongly backward directed branch, S2 to S4 short and simple; (3) fairly small palpebral lobes located slightly anterior to the cephalon's midlength and defined adaxially by a shallow and incompletely developed palpebral furrow; (4) eye ridges that originate near S4 and curve distinctly backward; (5) gently convex, never swollen fixigenae that are clearly wider (tr.) than half of the glabella's maximum width; (6) a moderately broad, distinctly convex anterior border; (7) anterior branches of the facial suture being subparallel close to the eyes, but clearly convergent in its anterior course; (8) strongly diverging posterior branches of the facial suture; (9) librigenae with a rounded posterolateral corner or a short genal thorn or spine; (10) a multisegmented thorax composed of subequal segments of simple, typical ptychoparioid morphology and with only small pleural spines; (11) a pygidium of sublenticular outline with an entire, more or less uniformly curved posterior margin; (12) a broad and fairly long pygidial rhachis; (13) pygidial pleurae without a consistent segmentation with a multitude of recognizable furrows; and (14) pygidial border and border furrow obsolescent. Change of proportions during ontogeny affects the validity of a number of species that are known only from sparse material and thus need to be treated with caution. Examples are Elrathina idahoensis (Resser, 1938) and E. parallela Rasetti, 1951, which indicate a considerable increase in tapering of the glabellar (personal communication, F.A. Sundberg, 2013).

The characters listed above indicate that a number of species assigned to the genus must be grouped among other genera. Elrathina danzhaiensis Zhou in Lu et al., 1974 from the Kaili Formation of the Danzhai area, Guizhou Province, South China, is distinguished from typical Elrathina species by its broad (sag.) preglabellar field, the narrow glabella, straight eye ridges directed almost normal to the axis, and a few other characters. The species has been transferred to Nangaops (Zhang et al., 1980; Zhao et al., 2001). Elrathina offula Resser, 1939 from the Spence Shale, collected near Liberty, Bear River Range, Idaho, has a strongly tapering glabella and is known only from distinctly distorted and unrecognizable cranidia. Elrathina spencei (Resser, 1939), also from the Spence Shale of Liberty, Bear River Range, Idaho, was first described as Elrathia spencei. The three figured specimens (Resser, 1939, pl. 6, figs. 15-17) probably belong to three different species, as indicated by different lengths of palpebral lobes at different positions in respect to the glabella and different breadths of the preglabellar field. Nevertheless, each of the specimens has a distinctly tapering glabella unlike Elrathina, and a pygidium that shows an indentation of the posterior pygidial margin. The librigena is unknown. Elrathina nodulosa Deiss, 1939 is based on a single cranidium from the Pagoda Limestone of the Lick Creek section, Montana. The small cranidium differs from typical Elrathina species in its strongly tapering glabella and fairly broad (sag.) preglabellar field. Elrathina turgida Bognibova in Chernysheva, 1971, from the Mundybash "Horizon" of the Tebe Mountains, eastern Tannu-Ola, in the Sayan-Altay foldbelt, is characterized by a distinctly tapering glabella with well-incised lateral glabellar furrows. The thorax, pygidium, and librigena are unknown. Elrathina wheelera Sundberg, 1994 is known from a number of samples from the Swasey Limestone and Wheeler Shale of the House Range, Utah, and the Pole Canyon Limestone and Lincoln Peak Shale of the Snake Range, Nevada. It has a subparallel glabella with a flattened to nearly indented front and a broad (sag.) preglabellar field with a distinct swelling - a feature that is unknown from any other species assigned to Elrathina. The thorax and pygidium are unknown, but Sundberg (1994, fig. 70.4, 70.5) figured two librigenae that show such distinct differences in the size and position of the ocular suture, the development of the lateral border furrow, and the genal thorn that they appear to belong to different species and genera.

Solov'ev and Grikurov (1978) described material from the Ptychagnostus praecurrens Zone of the Shackleton Range, Antarctica, as Elrathina parallela longa, and their naming suggested a new variety of E. parallela. The available material consisted of only two moderately well-preserved carapaces (one of them an external mold), which do not present details of the pygidium and the glabella. Solov'ev and Grikurov (1978, p. 197-198) emphasized the similarity with E. parallela, from which the specimens from the Shackleton Range were distinguished by a more slender glabella with subparallel sides and a narrow frontal lobe. In fact, this interpretation is based on the fact that the anterior part of the glabella in both specimens appears to be transversely compressed and therefore has a ridge that connects the glabella with the anterior border as a taphonomic artifact. We thus regard the type material of E. parallela longa as insufficient to characterize a taxon.

Elrathina antiqua Palmer in Palmer and Halley, 1979 from the Carrara Formation of the Belted Range, Nevada, is characterized by a pygidium with an unusually short axis, a thorax of only 15 or 16 segments, and librigenae with an angular thorn, but otherwise shares the diagnostic characters of the genus (Fig. 4.2). It is derived from the Albertella Zone and is thus the oldest known species of the genus.

The type species, Elrathina cordillerae, occurs in the Stephen Formation, and an assemblage of obviously closely related species occurs in similar or the same strata as the type species. These species include E. brevifrons, E. marginalis, E. parallela, and E. spinifera. If correctly assigned, these species provide a model for both intraspecific variation as well as the variation of characters within the genus. Elrathina brevifrons Rasetti, 1951 from the Stephen Formation at Mount Field, British Columbia, shares most characters with E. cordillerae, but has a distinctly shorter preglabellar field, more strongly impressed lateral glabellar furrows, an occipital furrow that tends to curve forward, a small occipital node only, a 

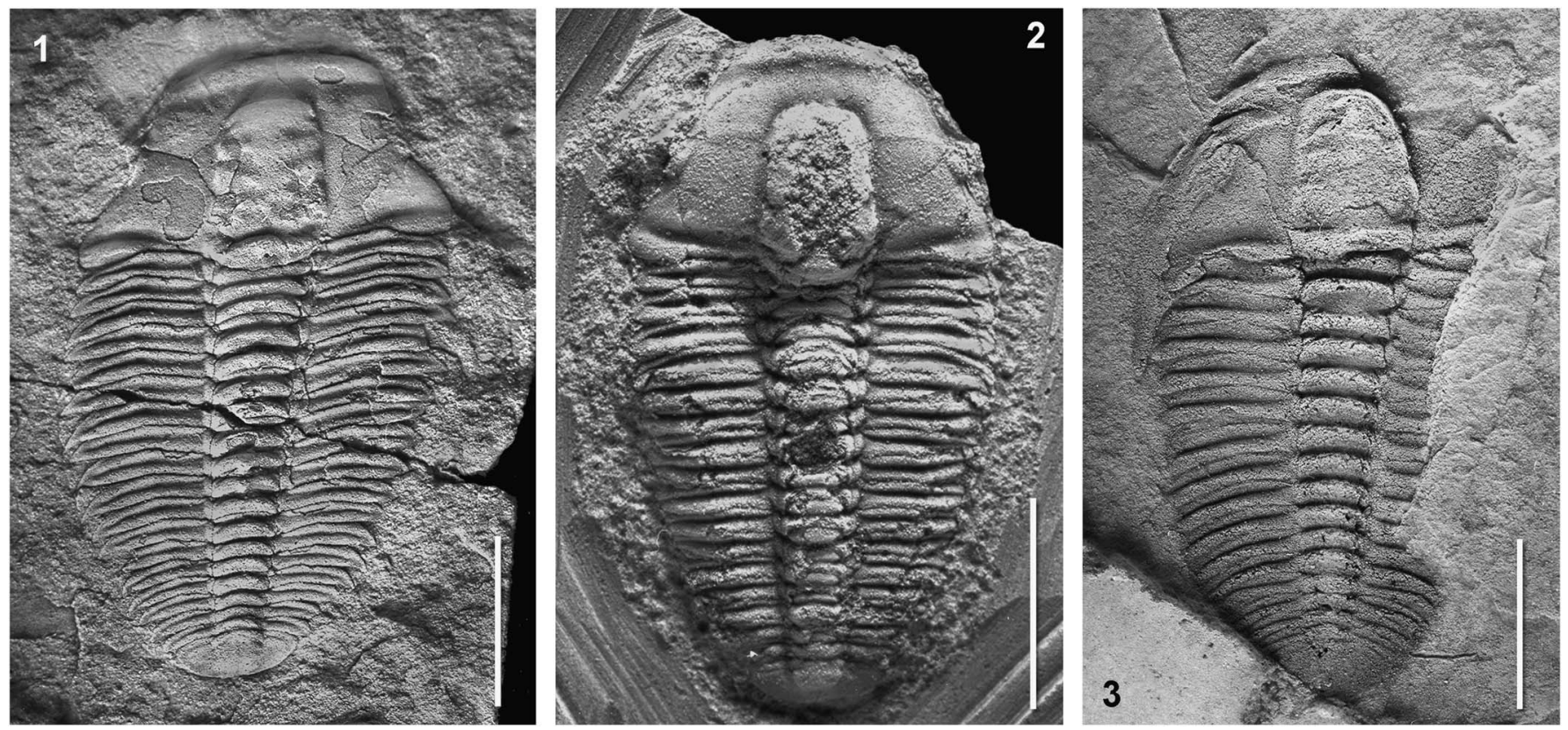

Figure 4. (1) Elrathina brevifrons Rasetti, 1951, holotype, USNM 116223, carapace without librigenae; long pygidial axis with bilobate rear end; Stephen Formation, Mount Field, British Columbia; (2) Elrathina antiqua Palmer in Palmer and Halley, 1979, holotype, USNM 208228, carapace without librigenae; Carrara Formation, Belted Range, Nye County, Nevada; (3) Elrathia georgiensis Resser, 1937b, plaster cast of holotype in the Museum of Comparative Zoology, Cambridge, Mass., USNM 65009, carapace without librigenae, Parker Slate, Parker Quarry, Georgia. Scale bars $=5 \mathrm{~mm}$.

longer pygidial rhachis that almost reaches to the posterior margin, and the geniculation of the thoracic pleurae is at a more adaxial position (Fig. 4.1). Elrathina brevifrons differs particularly from E. cordillerae in having a pygidial terminal piece that is not bilobate, which may separate the species on the generic level. Elrathina marginalis Rasetti, 1951 from the Stephen Formation of the Mount Odaray section, British Columbia, appears to be characterized by a stronger convexity of the carapace. It has a sagittally narrow preglabellar field, a distinct occipital node or thorn, and the geniculation of the thoracic pleurae is at a more adaxial position at about two-thirds of the distance from the axial furrows. The pygidium and librigenae are unknown.

Elrathina parallela Rasetti, 1951 (Fig. 6.15) from the Stephen Formation of Mount Stephen, British Columbia, is characterized by a moderately wide preglabellar field and a slight posterior mesial swelling of the anterior border. According to Rasetti (1951), the thorax consists of 17 or 18 segments, which have the geniculation of their pleurae at nearly two-thirds of its width (tr.) distant from the axial furrows. The pleural tips lack distinct spines and appear to be more or less truncated. Rasetti (1951) also suggested that the pygidial rhachis is more slender than in E. cordillerae, but this is not the case as shown in Figure 6.15, herein. By contrast, Rasetti's (1951) holotype indicates that E. parallela is the only other species with a tendency for a bilobate terminal axial piece (Fig. 6.15). Material from the Zacathoides gilberti fauna of the Cow Head Group of western Newfoundland identified as Elrathina parallela by Young and Ludvigsen (1989, pl. 9, figs. 8-13) has a distinctly shorter preglabellar field and a broader glabella in adult individuals. It appears to represent another, yet unnamed species, but more material is needed to characterize its morphology.

Elrathina spinifera Rasetti, 1951 from the Stephen Formation of the Mt. Odaray section, British Columbia, has a glabella with an almost flat front, a fairly narrow preglabellar field, a distinct swelling of the anterior border such that the anterior border furrow describes a rearward swing and is shallower on the sagittal line, and a short obliquely backward directed occipital spine. The thorax, pygidium, and librigenae are unknown.

Summarized, the species from the Stephen Formation indicate that specific differences include variation of the preglabellar field, the breadth and possible swelling of the anterior cephalic border, the size of the occipital node or spine, the position of the geniculation of the thoracic segments, and the length and width of the pygidial rhachis, all of which appear to be constant within the species. Therefore, these characters are regarded as a blueprint for taxonomic distinction within the Elrathina clade.

Another group of species from similar strata of northwestern Montana includes Elrathina nodulosa Deiss, 1939, discussed above as a problematic species that does not belong to Elrathina. It is based on a single small holaspid cranidium. Elrathina convexa Deiss, 1939 from the Pentagon Shale of the Lick Creek section, Continental Divide, northwestern Montana, is known only from the holotype, which is an incomplete carapace, only partly figured by Deiss (1939, pl. 15, fig. 2). It has a glabella with almost subparallel sides and a moderately large occipital node, a very narrow preglabellar field, and an anterior border that grows conspicuously in width towards the sagittal line. The geniculation of the thoracic pleurae occurs at about two-thirds of its transverse length from the axial furrow. The pygidium and librigenae are unknown. Elrathina erecta Deiss, 1939 from the Pagoda Limestone of the Lick Creek section, Continental Divide, is based on a single cranidium in which the glabella has subparallel sides and a subtruncate median sector of the glabellar front, but also well-recognizable lateral glabellar furrows. The preglabellar field is moderately 
broad (sag.) while the imperfectly preserved anterior border was probably narrow. The eye ridges are difficult to recognize and apparently very faint, but this may be a result of a slight abrasion of the surface due to mechanical cleaning of the specimen. The occipital node is small, the lateral glabellar furrows fairly well impressed, and the palpebral lobes lie at about cephalic midlength and thus in a more posterior position than usual for Elrathina species.

Elrathina fecunda Deiss, 1939 from the Pentagon Shale of the Lick Creek section, Continental Divide, is known from a number of specimens, including articulated exoskeletons without librigenae and an incompletely preserved carapace with librigenae in place. Deiss (1939, pl. 15, figs. 6-9) figured three specimens, which are interpreted here to belong to two different species. MSU T1148 (pl. 15, fig. 6; now housed in the U.S. National Museum under USNM 99122) has a tapering glabella with an almost flat front, a narrow preglabellar field, relatively think anterior border, a blunt occipital node and barely recognizable eye ridges; its librigenae are narrowly rounded at the corner and lack a spine or thorn. The holotype (MSU T1146, pl. 15, fig. 9) is a carapace without librigenae that more or less shows the same morphology as MSU T1148. It has a slightly less broadly developed occipital node and less obliquely arranged palpebral lobes. Its thorax has 18 segments, and the pygidium is broadly transverse, but has a wide rhachis. Both rhachis and pleurae seem to lack well-recognizable furrows. By contrast, specimen MSU T1147 (Deiss, 1939, pl. 15, fig. 7), a carapace without librigenae, has a strongly swollen anterior border that forces the anterior border furrow to curved rearward and create a shallow triangular process and to fuse more or less with the axial furrow in front of the glabella. The glabella has a similar shape and dimensions as in MSU T1146 and MSU T1148, but a more rounded front and a smaller occipital node. The thorax consists of 18 segments; the pygidium is not clearly visible. All of the specimens with preserved thorax have the geniculation at about mid-length of the pleurae. Elrathina hybrida Deiss, 1939 from the Pagoda Limestone of the Lick Creek section, Continental Divide, is based on small cranidia with (according to Deiss, 1939, p. 89) a punctate surface of the test. The holotype has a slender, moderately tapering glabella, a moderately broad (sag.) preglabellar field and a narrow anterior border. The palpebral lobes are in a strongly anterior position. Elrathina lickensis Deiss, 1939 from the Pagoda Limestone of the Lick Creek section, Continental Divide, also has a moderately tapering glabella, which is wider than that of E. hybrida, very shallow curvature of its frontal lobe, and a low occipital node. The preglabellar field is moderately broad (sag.), and the anterior border is narrow to moderately wide. The surface is covered by minute granules. Elrathina oculineata Deiss, 1939 from the Pentagon Shale of the Lick Creek section, Continental Divide, known from a single cranidium, has a strongly tapering glabella and distinct eye ridges, a moderately broad (sag.) preglabellar field, and a prominent, moderately broad anterior border that grows considerably in width to the sagittal line. According to Deiss (1939), the surface is minutely punctate. The single specimen has suffered slight distortion and is insufficient to characterize a readily recognizable species. It is impossible to confidently clarify the status of Deiss' (1939) species without recollection and careful analysis of additional specimens from the type localities. Schwimmer (1973) recognized only two species:
Elrathina fecunda, with $E$. convexa and $E$. oculineata suggested as synonyms; and E. erecta, with E. lickensis and E. hybrida as synonyms.

Taphonomy.-The most conspicuous taphonomic effect in Elrathina is the absence of librigenae even in the nearly complete carapaces. These therefore qualify as carcasses that record the "olenid mode" of molting.

A common feature in larger sclerites is the presence of cracks. Their frequency depends on the size and morphology of the sclerites. Isolated thoracic segments are generally preserved as fragments only, which is interpreted as an effect of the narrow and brittle nature of the segments. Their fractures are concentrated at or adjacent to the axial furrow.

The distribution pattern of fractures in the cranidium resulting from dorsoventral compaction during early diagenesis is noteworthy. Other than in species of ellipsocephaloid and fallotaspidoid trilobites, the location of the fractures does not follow particularly the location of furrows and cephalic sutures (compare Geyer, 1996). Nevertheless, four preferred locations of the cracks can be seen (Fig. 5): (1) subsagittal fractures tend to commence slightly exsagittal from the median axis and extend obliquely to meet the anterior parts of the axial furrows; most of them meet the anterior part of the glabella in an angle of $30-45^{\circ}$ in respect to the sagittal line, but show a tendency to slightly curve towards the axis when reaching prominent/ convex parts of the glabella; (2) the ocular suture or the palpebral lobe is commonly the locus of another set of cracks due to the circumocular suture, which delineates a major weakness in the stiff cephalic sclerites, especially after release of the visual surface; the orientation of the cracks with respect to the cephalic median axis, however, is obviously not a direct response to vectors of major strain but a secondary phenomenon during compactional fracturing, thus the resulting cracks run from the palpebral lobes or the depression immediately posterior to it in an oblique direction of roughly $45^{\circ}$ to the sagittal line towards the medial axis and mostly end at or shortly adaxially of the axial furrow, often with a slight rearward curvature on the lateral portions of the glabella; (3) a less-clear pattern of sagittal or exsagittal fractures exists on the glabella, some of them

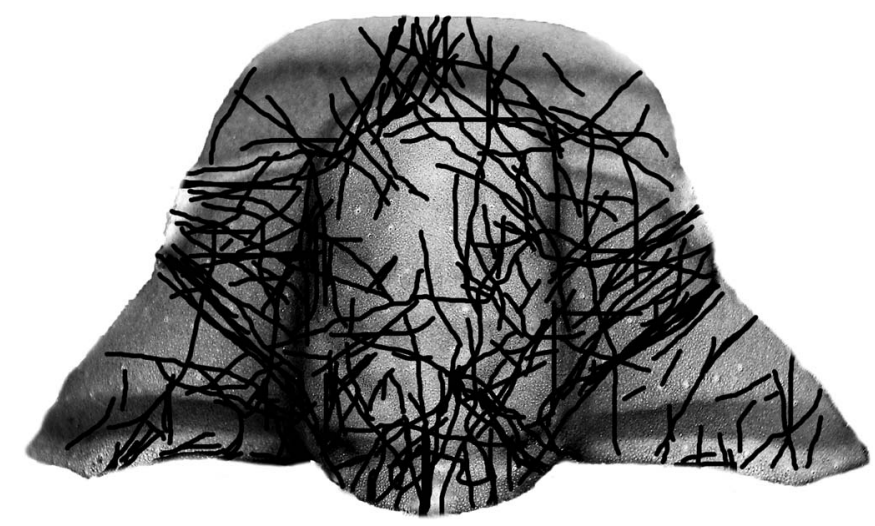

Figure 5. Schematic camera lucida drawings of fractures imposed on a single cephalon of Elrathina. The pattern of fractures resulted from dorsoventral compaction of the sclerites and indicates the frequency of fracture orientations seen in the Ekspedition Bræ species E. aphrodite n. sp., E. athena n. sp., and E. hera n. sp. 
terminating in short curved sections, which probably reflect fine-scale differences in the convexity and the thickness of the test; and (4) a swarm of mostly narrow fractures affects the posterolateral extensions of the fixigenae and the adjacent posterior border furrow and posterior border; these show a wide range of directions that effectively record exsagittal fracture perpendicular to the main stress direction.

\section{Elrathina cordillerae (Rominger, 1887)}

Figure 6.4-6.14

1887 Conocephalites cordillera Rominger, p. 17, pl. 1, fig. 7.

1888 Ptychoparia Cordillera; Walcott, p. 165.

?1899 Ptychoparia cordillera; Matthew, p. 44, pl. 1, fig. 7a, 7b.

1902 Ptychoparia Cordillera; Woodward, p. 536, text-fig. 4. 1908 Ptychoparia cordillera; Walcott, p. 243, pl. 3, fig. 5. ?1912 Ptychoparia cordillera; Walcott, p. 190, pl. 24, fig. 2. 1918 Ptychoparia cordillera; Walcott, p. 144, pl. 21, fig. 4. ?1918 Ptychoparia cordillera; Walcott, pl. 21, fig. 3, 5.

1937a Elrathina cordillerae; Resser, p. 6.

?1950 Elrathina cordillerae; McLaughlin and Enbysk, p. 469, pl. 65, figs. 12, 15-17.

non 1950 Elrathina cordillerae; McLaughlin and Enbysk, pl. 65, fig. 14.

1951 Elrathina cordillerae; Rasetti, p. 221, pl. 26, figs. 7-9.

non 1979 Elrathina cordillerae; Conway Morris, p. 329.

1999 Ptychoparella cordillera (Rominger, 1887); Sundberg, p. 1140, fig. 3, appendix 3.

?2003 Ptychoparella cordillerae; Fletcher and Collins, p. 1833, fig. 5.17 .

non 2008 Elrathina cordillerae; Caron and Jackson, p. 226, tab. 1.

Type material.-Resser (1937a) selected a lectotype (termed "holotype" in Resser, 1937a, p. 11), which he did not figure, but mentioned that it was deposited as a cast in the U.S. National Museum, Washington, D.C., under USNM 17831. According to the ICZN rules, a lectotype must be from the original collections of the Academy of Natural Sciences, Philadelphia. Plesiotypes listed by Resser (1937a) are housed under the numbers 65518 and 57658; these numbers also refer to specimens deposited in the U.S. National Museum. The U.S. National Museum collection USNM 17831 includes six plaster and four (partly broken) gutta-percha casts, as well as four additional rock slabs, all with specimens of Elrathina. However, some of the casts are made from the attached rock samples, but none of them can be matched to Rominger's type material, which is now deposited in the University of Michigan Paleontological Museum, Ann Arbor, Michigan.

Diagnosis.-Species of Elrathina with subparallel to slightly tapering glabella with a shallow rounded front; palpebral lobes small, but not minute, distinctly anterior to the cephalon's half; eye ridges with only gentle curvature; anterior border narrow to moderately broad (sag.), occasionally with a minute to considerable medial swelling at its rear side; preglabellar field of variable sagittal width; librigenae with rounded posterolateral corner; geniculation of thoracic pleurae slightly abaxially to pleural mid-length; pygidium sublenticular to subelliptical outline; pygidial rhachis broad, with one to three rings, its posterior end with pair of slightly inflated bulbs separated by a longitudinal furrow, reaching to or almost to the posterior margin; pygidial pleurae with two or three furrows.

Remarks.-The type species, Elrathina cordillerae, was introduced as Conocephalites cordillerae by Rominger (1887) and shown in a single figure (Rominger 1887, fig. 7), which provides a completely erroneous impression of its morphology. Fortunately, Rominger's original material from the well-studied Stephen Formation from Mount Stephen, British Columbia, is preserved as a type lot recorded as eight syntypes on six slabs in the University of Michigan Paleontological Museum, most of them being relatively complete carapaces lacking librigenae. The lot also includes two additional incomplete specimens. The type material is not perfectly preserved, but shows enough details to characterize the species.

The characters of the type material of Elrathina cordillerae are summarized in the diagnosis. In addition, S1 is long, faintly bifurcate and strongly backward directed. The occipital ring bears a node or thorn. The thorax consists of 17 or 18 segments in adult specimens, with simple, typical ptychoparioid morphology and probably with only small pleural spines. The small pygidium has an obsolescent border and border furrow (Fig. 6.8, 6.9, 6.14). Unfortunately, no librigena is known from the type material and the specimens do not present details of distal sections of the eye ridges, the occipital node, or the anteriormost section of the thoracic pleural tips.

Walcott (1908, pl. 3, fig. 5) figured a drawing of a specimen that shows two distinct furrows on the pygidial pleural areas, but a short rhachis without furrows and of less than half pygidial length. By contrast, Walcott (1918, pl. 21, fig. 4) presented a drawing of a specimen with the described pygidial morphology visible in the type lot. The specimen has been located in the USNM collection and is shown here (Fig. 6.11). This specimen is a complete carapace with librigenae that have a rounded posterolateral corner and thus lack a genal spine. Additional specimens housed in the USNM collection under the same number, and thus presumably from the same collection, have partly well-preserved librigenae with a strongly rounded posterolateral corner and a strongly curved posterior branch of the facial suture (Fig. 6.12, 6.13). The thorax consists of 18 or 19 segments, with pleural tips ending in short spines or thorns. It should be emphasized that the glabella in Walcott's (1918) specimen tapers anteriorly, but this, in part, is a result of dorsoventral compaction (Fig. 6.11).

Matthew (1899, pl. 1, fig. 7a, b) presented drawings of a partial carapace and a pygidium, which are difficult to assess. The librigenae shown in Figure 7a suggest a genal spine, but this appears to be an interpretation introduced by Matthew that was triggered by figures of the Furongian genus Olenus. The pygidium is reminiscent of the shape of Elrathina n. sp. (see below) more than to E. cordillerae, but Matthew indicated a furrowed rhachis with several rings and pleural furrows.

Rasetti (1951, pl. 26, figs. 7-9) figured three almost complete specimens, one from the Phyllopod bed of the Burgess Shale quarry site at Mount Field and two from the Ogygopsis Shale at Mount Stephen. At least two of the specimens show the pygidial 

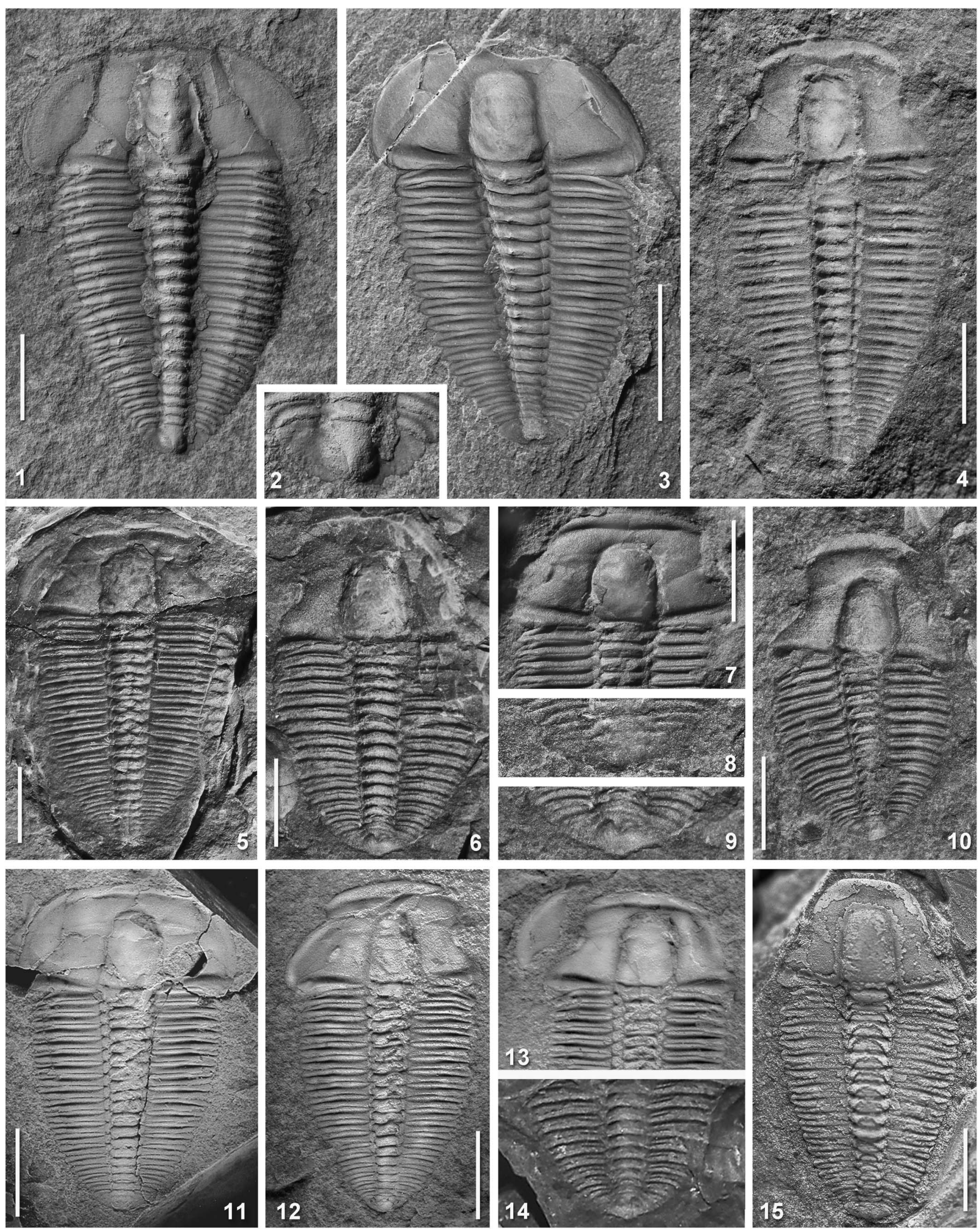
morphology of Rominger's material, with a distinctly furrowed pygidial rhachis and pleural areas, and two have more or less attached librigenae with a rounded corner. It is noteworthy that the width of the anterior border appears to vary, and one specimen (pl. 26, fig. 9) shows a small medial swelling of the anterior border. The figured specimens have either 18 or 19 thoracic segments, although Rasetti (1951) stated that he found specimens with 17 or 18 and rarely 19 segments.

Surprisingly, almost all specimens from the Burgess Shale show differences from this morphology. These specimens have a similar morphology to those from the type lot of E. cordillerae and those presented by Rasetti (1951). However, their pygidium has a sublenticular to subelliptical outline with a broad pygidial rhachis that lacks clear segmentation except for one shallow furrow; its posterior end is not divided into two lobes and clearly distant from the posterior margin; and the pygidial pleurae have only one clearly recognizable furrow (Fig. 6.1-6.3). Other noteworthy characters include a slightly tapering glabella with a shallow rounded front; a poorly defined palpebral furrow; a strong occipital node or thorn; librigenae with a rounded posterolateral corner, and thus lacking a genal spine; and a thorax of $\sim 18$ segments of simple, typical ptychoparioid morphology and with small pleural spines. These specimens belong to a new species described informally below.

\section{Elrathina new species Figure 6.1-6.3}

Remarks.-The typical material of the Burgess Shale (e.g., Conway Morris, 1979; Caron and Jackson, 2006; material of the Royal Ontario Museum under <http://www.burgess-shale.rom.on.ca/en/ fossil-gallery/view-species.php?id=7\&ref=i\& $>$ [accessed October 2016]) differs in a number of characters from Rominger's type material of Elrathina cordillerae so that it must be regarded as a different, not formally introduced species. These characters include a subparallel to slightly tapering glabella with a shallow rounded front; short palpebral lobes located distinctly anterior to the cephalon's mid-line; eye ridges with only a gentle curvature; a narrow to moderately broad (sag.) anterior border; a preglabellar field of variable sagittal width; librigenae with rounded posterolateral corner; thoracic pleurae, in which the geniculation is located slightly abaxially to pleural mid-length; a pygidium with sublenticular to subelliptical outline; a broad pygidial rhachis with only one ring and with a rounded posterior end distant from the posterior margin; and pygidial pleurae with only one recognizable furrow.

The new species is thus primarily distinguished from E. cordillerae by its smoother pygidium with a shorter and less-structured rhachis. It should be noted that specimens of the new species in the typical preservation in mudstones occasionally show a marginal band that mimics a lateral border (Fig. 6.3). This feature, however, is a result of the ventral doublure impressed through the dorsal side of the carapace (see under Elrathina romingeri).

Numerous specimens of this new, undescribed species are known from the Burgess Shale of the Walcott quarry on Fossil Ridge in the Yoho National Park, British Columbia, where is it known from mass assemblages such as a cluster with more than 40 specimens reposited as ROM 59549 (Burgess Shale fossil gallery, <http://burgess-shale.rom.on.ca/en/fossil-gallery/viewspecies.php?id $=7 \& \mathrm{~m}=3 \&>$ [accessed October 2016]). These occurrences are from the Bathyuriscus-Elrathina Zone in the Stephen Formation. However, the same species is also known from the Trilobite Beds at Mount Stephen, which belongs to the Glossopleura Zone of the Stephen Formation, so that a distinct stratigraphic separation from E. cordillerae does not exist.

\section{Elrathina aphrodite new species}

Figures 7.1-7.12, 8

Holotype.-MGUH 30907 (Fig. 7.1, 7.2, 7.4, 7.7). Western side of Henson Gletscher, Lauge Koch Land, North Greenland, middle part of the Ekspedition Bræ Formation, GGU sample 225501 .

Paratypes.-Western side of Henson Gletscher, Lauge Koch Land, GGU sample 225501: three exoskeletons without librigenae (under MGUH 30911, and 30910), one incomplete carapace (MGUH 30909), two meraspid cranidia (MGUH 30913 and 30912); western side of Løndal, GGU sample 255720: one almost complete carapace without librigenae (under MGUH 30908).

Diagnosis.-Species of Elrathina with subparallel to slightly tapering glabella, glabellar front with shallow curvature only, almost subtruncate in median sector; palpebral lobes small, but not minute, distinctly anterior to the cephalon's half; eye ridges with gentle curvature; anterior border with rearward swelling that creates triangular extension; anterior border furrow nearly

Figure 6. (1-3) Elrathina n. sp. (1, 2) ROM 53273, complete carapace; (1) dorsal view of specimen with imprint of ventral cephalic doublure; (2) close-up of Fig. 6.1; Glossopleura Zone, Stephen Formation, Trilobite Beds, Mount Stephen, British Columbia; length of specimen 23 mm; (3) ROM 60742, complete dorsoventrally flattened carapace with slightly detached librigenae, dorsal view; with single furrow on pygidial pleural fields; Bathyuriscus-Elrathina Zone, Stephen Formation, Walcott quarry, Fossil Ridge, British Columbia; (4-14) Elrathina cordillerae (Rominger, 1887); (4) UMMP 4883.1, dorsal carapace without librigenae, dorsal view; note distinct medial broadening of anterior border; Glossopleura Zone, Stephen Formation, Trilobite Beds, Mount Stephen, British Columbia; (5, 8) UMMP 4883.2, dorsal carapace without left librigenae; Glossopleura Zone, Stephen Formation, Trilobite Beds, Mount Stephen, British Columbia; length of specimen $19.5 \mathrm{~mm}$; (5) dorsal view of entire specimen; (8) close-up of Fig. 6.5; (6, 9) UMMP 4883.3, dorsal carapace without librigenae; Glossopleura Zone, Stephen Formation, Trilobite Beds, Mount Stephen, British Columbia; length of specimen 22 mm; (6) dorsal view of entire specimen; (9) close-up of Fig. 6.6; (7) UMMP 4883.4, cranidium with attached incompletely preserved thorax, detail; Glossopleura Zone, Stephen Formation, Trilobite Beds, Mount Stephen, B.C.; (10) UMMP 4883.5, dorsal carapace with slightly detached thoracopygidial unit of immature individual, dorsal view; Glossopleura Zone, Stephen Formation, Trilobite Beds, Mount Stephen, B.C.; (11) USNM 65518a, incomplete dorsal carapace; Stephen Formation, Mount Stephen, B.C. (original of Walcott, 1918, pl. 21, fig. 4); (12) USNM 65518g, incomplete dorsal carapace with detached librigenae; Stephen Formation, Mount Stephen, B.C.; (13) USNM 65518f, incomplete dorsal carapace with detached librigenae; Stephen Formation, Mount Stephen, B.C.; note strongly curved posterior branch of suture; $\times 2.7$; (14) under lot USNM 17831, posterior part of thorax and pygidium; Stephen Formation, Mount Stephen, B.C.; original specimen stored with plaster and gutta-percha casts with the collection number provided by Resser (1937a) as characterizing the "holotype;" $\times 2.3$; (15) Elrathina parallela Rasetti, 1951; USNM 116279, holotype (Rasetti, 1951, pl. 33, fig. 20), incomplete dorsal carapace without librigenae; Stephen Formation, Mount Stephen, B.C. All scale bars $=5 \mathrm{~mm}$. 

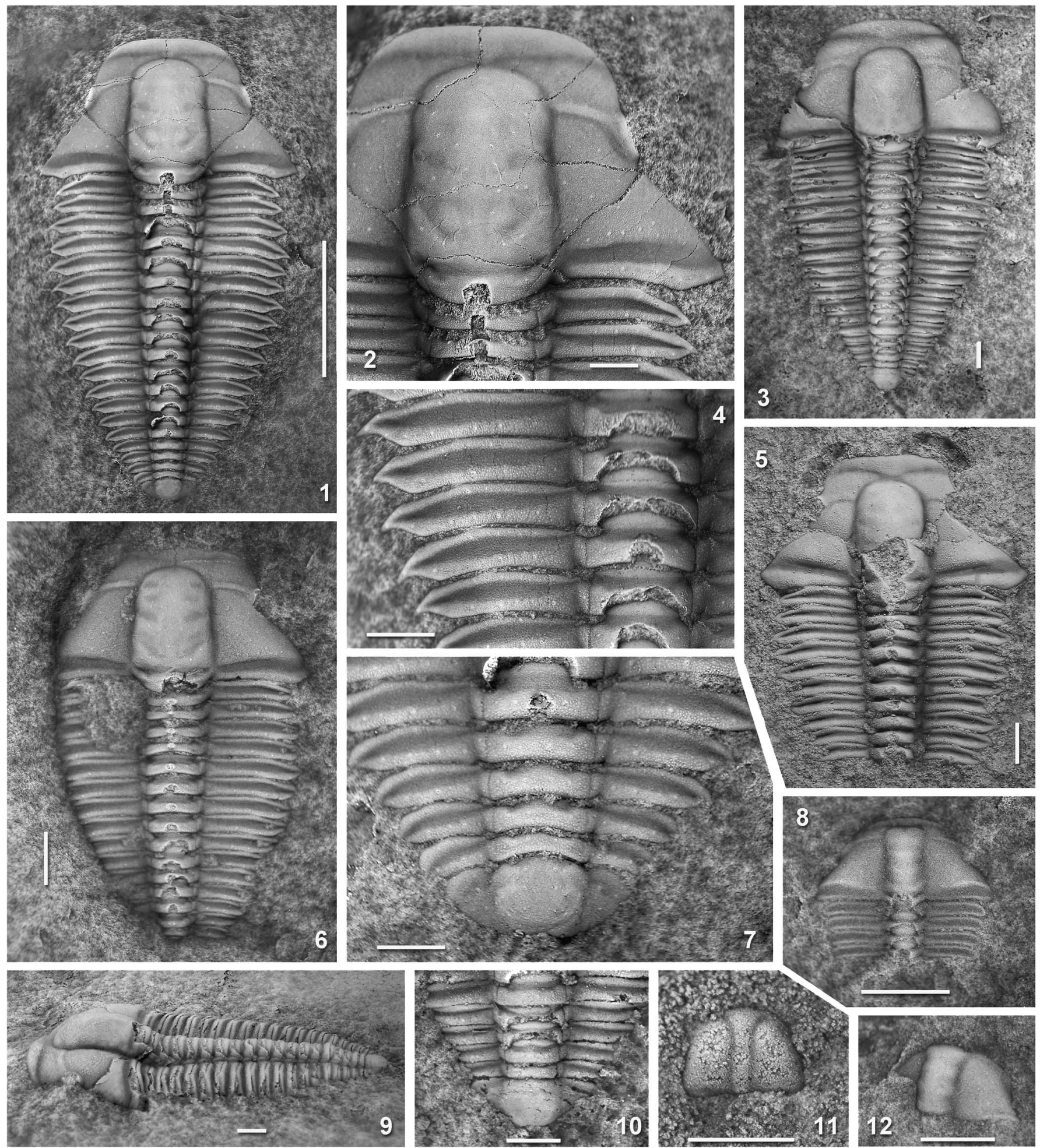

Figure 7. Elrathina aphrodite n. sp.; (1, 2, 4, 7) Holotype, MGUH 30907, latex cast of external mold, carapace without librigenae; (1) entire specimen, scale bar $5 \mathrm{~mm}$.; (2) close-up of $1 ;$ (4) thorax segments $3-7$; (7) posterior thorax and pygidium; $(\mathbf{3}, \mathbf{9}, \mathbf{1 0})$ Paratype, MGUH 30908, medium-sized carapace without librigenae, partly exfoliated; (3) dorsal view of entire specimen; (9) lateral view showing flexure in anterior part of thorax; (10) close-up of Fig. 7.3. (5) Paratype, MGUH 30909, incomplete carapace; (6) Paratype, MGUH 30910, carapace without librigenae, latex cast of external mold; (8) Paratype, MGUH 30911, incomplete meraspid carapace, dorsal view; note narrow subparallel glabella and transversely slender, almost straight pleurae; (11) Paratype, MGUH 30912, early meraspid cranidium; (12) Paratype, MGUH 30913, latex cast of late meraspid cranidium, slightly oblique view. All scale bars = $1 \mathrm{~mm}$, except in Fig. 7.1 .

confluent or confluent with furrow in front of glabella; anterior branches of facial suture straight to gently curved for most of its course; geniculation on thoracic pleurae slightly distant to pleural mid-length; pygidium subsemicircular in outline; rhachis poorly subdivided, posterior tip almost reaches to posterior margin; surface of test densely covered with minute granules 
inclusive of most furrows, glabella, fixigenae, and axial rings with prosopon of moderately large, widely spaced granules.

Description.-Cranidium subtrapezoidal in outline, with strongly extending posterolateral portions and slightly convergent to almost subparallel anterior branches of facial suture. Ratio length to width across palpebral lobes $\sim 0.85$; ratio length to width across posterolateral processes of genae slightly less than 0.60 .

Glabella transversely distinctively convex, lateral profile gently convex in the posterior half, progressively sloping towards anterior; with subparallel sides or faintly tapering forward from occipital furrow to S4 to $\sim 90 \%$ of maximum width; slight constriction along line drawn to connect S2; frontal lobe with rounded anterolateral corners, front with low curvature; length $\sim 85 \%$ of cephalic length (inclusive occipital ring) in adult individuals, transverse width across $\mathrm{L} 145-49 \%(\mathrm{~N}=7)$ of transverse cranidial width across posterior tips of palpebral lobes in undeformed specimens. Four pairs of glabellar furrows recognizable in well-preserved specimens, all shallow and poorly marked near axial furrows, progressively less well impressed from S1 to S4, fading towards midline; S1 a bifurcate depression with a longer posterior branch directed strongly backward from axial furrows and almost straight, short and almost hook-shaped anterior branch strongly anteriorly curved; S2 a slightly backward directed, shallow, longitudinally drop-shaped depression; S3 very shallow, ovate depressions disconnected from axial furrows; S4 narrow obsolescent transverse depressions more or less normal to axis. Occipital furrow consists of obliquely backward directed, narrow and deep lateral sections and a shallower and broader, nearly straight median section. Occipital ring with low convexity in sagittal section or almost level in median sector of adult specimens, more strongly convex in juvenile individuals; posterolateral margin steep and backward swinging and a gently curved median section; lateral portions fairly narrow; sagittal length $\sim 10-12 \% \quad(\mathrm{~N}=7)$ of cephalic length; with distinct median node.

Axial furrows well marked, moderately deep to shallow laterally, slightly narrower (sag. and exsag.) in front of glabella. Palpebral lobe fairly short, in adult individuals exsag. of $17-19 \%$ $(\mathrm{N}=7)$ of cephalic length (longer in juveniles), somewhat oblique to axis, anterior end in transverse line with L3, posterior end about in transverse line with S2; palpebral lobe prominent, usually developed as a narrow and distinctively upturned longitudinal bulge, rises steeply from a low ridge that originates from the posterior end of the eye ridge and obviously covers the visual nerves located below the carapace (Fig. 7.2); ocular suture almost a straight line in dorsal view; palpebral furrow shallow, merely a change in convexity, defined anterolaterally by a faint, low and narrow ridge originating from near the posterolateral end of eye ridge, which itself is paralleled towards the palpebral lobe by the aforementioned low ridge that originates from the posterior end of the eye ridge. Eye ridge forms low to moderately elevated, slightly curved lobes directed inward and slightly forward to meet axial furrow opposite S4; posterior end trifurcated into a narrow to moderately broad middle thread confluent with the base of the palpebral lobe, a narrow and faint adaxial thread adjacent to palpebral furrow, and a short and faint to obsolescent anterior thread that runs straight to the anterior tip of the palpebral lobe (Fig. 7.2); the adaxial end of the eye ridge crosses the axial furrow with a narrow and faint thread that is confluent with the posterior part of the glabellar frontal lobe.

Fixigena gently convex, moderately wide (tr.), transverse width between posterior ends of palpebral lobe and axial furrow 46-49\% ( $=7$ ) maximum glabellar width in adult individuals. Posterior area of fixigena extends into long, wing-like posterolateral projection (Fig. 7.2).

Anterior border gently convex, moderately broad, growing in width from the suture to the sagittal line and with a rearward swelling that creates a generally distinct triangular extension, variably of $12-16 \%(\mathrm{~N}=5)$ of cephalic length on sagittal line; median section of anterior margin weakly curved to almost straight in dorsal view. Anterior border furrow moderately wide (sag. and exsag.), shallow, curved posteriorly along the median extension of the anterior border and often confluent with axial furrow in front of frontal lobe (e.g., Fig. 7.2). Preglabellar field very narrow to absent. Genal fields moderately to distinctly convex, exsag. moderately broad, distinctively sloping ventrally towards anterior border furrow. Anterior branch of suture convergent or almost subparallel from anterior ends of eyes, curved inward when meeting the anterior border furrow and cutting a big portion off the anterior border. Posterior border narrow (exsag.) near axial furrow, directed slightly posterolaterally with a gentle curvature and slightly growing in breadth (exsag.) up to about two-thirds distance from posterolateral tips; gently to distinctly convex, often with the tendency of a flattened dorsal surface in exsag. section. Posterior border furrow moderately wide (exsag.), often slightly wider than border, moderately deep, slightly shallower towards the posterior branches of suture.

\section{Librigena and hypostome unknown.}

Thorax of 19 segments in adult individuals of studied material. Axial rings of segment 3 to 19 of more or less uniform shape (sag. and exsag.), length and width reduced progressively posteriorly (Fig. 7.1). Transverse width of average axial ring $\sim 26-29 \%(\mathrm{~N}=5)$ of overall width of the segment, growing in relative width to $45 \%$ in the posteriormost segment. Narrow (sag. and exsag.) articulating furrow with apodemal pit distally. Each ring with a moderately large, prominent short axial thorn and with lateral inflations indicating attachment sites of ventral muscles. Greatest width (tr.) at segments 3 to 5, decreasing progressively in width (tr.), with slightly but progressively backward-directed pleurae in the posterior four or five segments of the thorax. Pleural furrows moderately broad to broad (exsag.), forming faintly bent, narrow lenticular furrows with a relatively sharp anterior and a less-well-defined posterior margin, somewhat oblique to transverse axis, fading short distance from pleural tips. Pleural tips extend into short, needleshaped and slightly posterolaterally directed spines that develop from a gently curved anterior margin and an s-shaped distinctive posterior indentation of the pleurae. In anterior view, the pleurae show a distinct geniculation at about transverse mid-length, which corresponds with the articulation of adjacent segments by means of a fulcral point. As a result, the anterior flanks of the distant pleural portions have an almost flat although narrow articulating facet, whereas the posterior margin of the distal pleura turns slightly forward to allow a limited overlap of adjacent segments during inclination of the segments. First thoracic segment differs in having an axial ring, the anterior 
margin of which swings clearly backward to allow a distinct dorsal flexure of the cephalon against the thorax. Its pleurae are straight in the proximal sector, but show a well-developed fulcral point to fit into the socket of the cephalon's posterior border; distal part of pleura reduced in size, with a distinctly backward-directed anterior margin and an obliquely ventrally articulating facet so that the distal portion has a narrow triangular shape in dorsal view (Fig. 7.2). This configuration is repeated in a less-distinct manner in the second thoracic segment.

Pygidium subsemicircular in outline, length $\sim 48 \%(\mathrm{~N}=3)$ of maximum width (tr.). Rhachis a wide, poorly subdivided, moderately to strongly convex axis, the well-rounded posterior tip of which almost reaches the posterior margin; width (tr.) at anterior ring $~ 50 \%$ of maximum pygidial width; only one axial ring marked by a broad and indistinct, more or less transverse furrow. Posterior end of axis with indistinct luniform, basal swelling that suggests presence of a platform-like plectrum, now fused with the axis. Pleural fields with only one pair of broad and indistinct, rearward-curved pleural furrows. Pygidial border and border furrow absent. Lateral and posterior margins entire.

Ontogeny.-The studied material includes a few larval remains and immature specimens that can be tentatively assigned to Elrathina aphrodite n. sp.; three of these are well preserved and figured. The smallest specimen is an early meraspis (Fig. 7.11) preserved as a convex, almost semicircular shield with a fairly well-defined and extremely slender glabella with subparallel sides in the posterior four-fifths, and a distinct expansion of the frontal section. Pre-occipital glabellar segments are not apparent. Palpebral lobes are visible and located along the anterolateral margin, at $\sim 50^{\circ}$ if the shield is regarded as a half-circle with the base at the posterolateral corner. The palpebral lobes develop into eye ridges that form low ridges along the anterior margin of the shield and proceed into a faint and thin lobe that borders the glabellar front in the manner of a parafrontal band.

A later meraspid specimen is preserved as an incomplete carcass with the cranidium and four articulated thoracic segments (Fig. 7.8). Its cranidium is still only about $1 \mathrm{~mm}$ in length and the glabella is subparallel for approximately three-quarters of its length, with a slightly expanding front consisting of a pair of subglobular bulges separated at the front by a faint sagittal depression. The glabella is already clearly separated from a narrow occipital ring by a sharp transglabellar occipital furrow (incompletely preserved in the specimen) and is further subdivided by four pairs of shallow lateral glabellar furrows that are faintly connected medially. The cranidium has a thin but welldeveloped and upturned anterior border, curved eye ridges distant from the anterior border and connected with well-developed small palpebral lobe oblique to the axis, and a well-developed, long facial suture. The thoracic segments are surprisingly slender (exsag.) and straight for most of its transverse extension. A slightly larger, isolated cranidium shows a similar morphology with a slightly broader glabella, the front of which reaches close to the anterior margin, shallow, but well recognizable lateral glabellar furrows, and lenticular, comparatively long palpebral lobes (Fig. 7.12).
Prosopon.-Elrathina aphrodite n. sp. has a conspicuous bimodal prosopon composed of small to minute granules and larger tubercles. While the tiny granules cover the dorsal shield in subequal density, the larger tublercles are widely spaced, with the space between them occupied by the minute granules. Although the large tubercles are not perfectly preserved in the present material, it can be seen that they have a low domeshaped form with a central opening, the presence of which suggests a sensory organ. It is particularly remarkable that the distribution pattern of the large tubercles is roughly bilaterally symmetrical (Fig. 8); a pattern that has not yet been recorded from other ptychoparioid trilobites.

The surface of the cranidium, inclusive of most furrows, is densely covered with minute granules (Fig. 7.2). The glabella, fixigenae, preocular fields and posterior border carry the moderately large and relatively prominent tubercles in a roughly bilaterally symmetrical arrangement (Fig. 7.1, 7.2). The anterior parts of fixigenae, preocular fields, and anterior border show traces of radial caeca.

The surface of thoracic segments, inclusive of most furrows, is also densely covered with minute granules. Axial rings and prominent parts of middle sections of pleurae have moderately large and widely spaced tubercles (Fig. 7.1, 7.7).

The pygidial surface is covered by the minute granules and occasional faint and short terrace ridges that are arranged parallel to the margin. Moderately large, widely spaced tubercles are present, arranged in a more or less bilaterally symmetrical pattern (Fig. 7.7).

Etymology.-Named after the Greek goddess of love and beauty, Aphrodite, the winner of the 'judgment of Paris'; a reference to the common occurrence of three similar species with high esthetic qualities.

Remarks.-Elrathina aphrodite n. sp. is distinguished from other species of the genus by the combination of the: (1) distinct triangular extension of the anterior borders posterior margin; (2) relatively broad glabella with subparallel sides; (3) relatively stout, almost semicircular pygidium with a conspicuously wide

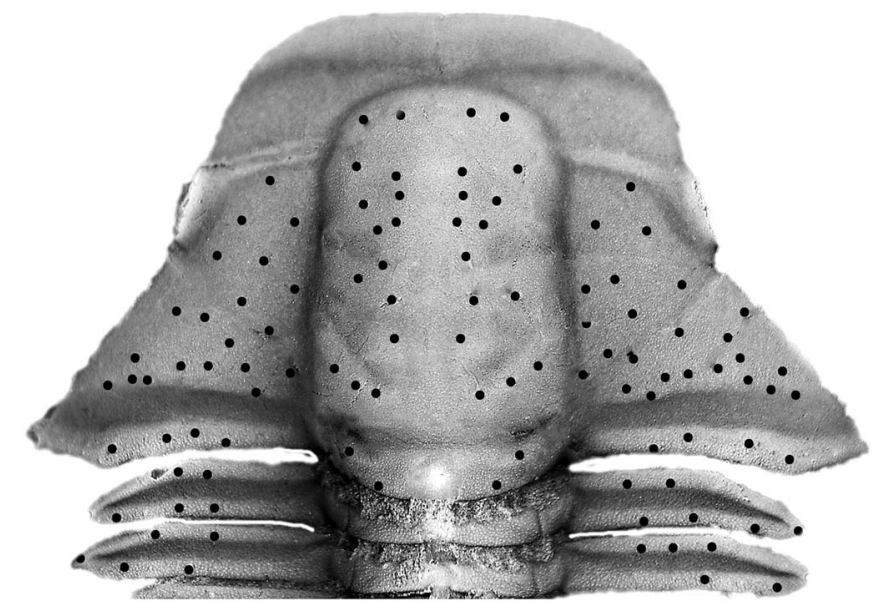

Figure 8. Elrathina aphrodite n. sp. Distribution of the larger tubercles on the cranidium marked by dots. Note the roughly bilaterally symmetrical arrangement. Magnification approximately $\times 10$. 
axis that almost reaches to the posterior margin of the pygidium; and (4) presence of a fine granulation with a superimposed, almost bilaterally symmetrical pattern of widely spaced larger granules. Except for the characteristic prosopon, all of these individual characters are known from other species of the genus, but never combined. The prosopon is possibly a character of other species as well, but would be visible only in wellpreserved material.

The obvious rearward extension of the anterior border varies to a certain extent within the studied material (e.g., Fig. 7.2, 7.3). A similar specimen is shown among the paratypes of Elrathina fecunda Deiss, 1939 (Deiss, 1939, pl. 15, fig. 7), but this specimen varies in several aspects from the holotype and additional material of $E$. fecunda. Other species with a slight to moderately swollen anterior border are E. athena n. sp., described below, and, in a much less conspicuous manner, in E. spinifera Rasetti, 1951. The feature is developed occasionally in E. parallela and E. cordillerae. In all of these species, the swelling does not grow to a size that completely reduces the preglabellar field.

The most similar species is the contemporaneous Elrathina athena, which at first glance may be confused with E. aphrodite n. sp. Elrathina athena n. sp. has a glabella that is wider across the occipital ring and L1 and tapers more strongly, with better-developed anterolateral corners; the swelling on the anterior border is less arcuate; and the anterior branches of the cephalic suture are distinctly more curved so that the anterior border appears more clipped anterolaterally. The pygidium of E. athena n. sp. is slightly wider and has a less-broad rhachis.

Elrathina hera n. sp., co-occurring with E. aphrodite n. sp., is distinguished by an even more clearly tapering glabella; an anterior border with only a slight to moderate median swelling, and thus a moderately broad (sag.) preglabellar field; palpebral lobes in a slightly more anterior position; an even wider pygidium with an axis of moderate width, as normal for the genus, and two furrows on the pleural areas; and lack of the distinct prosopon of granules. In addition, the geniculation of the thoracic pleurae tends to be located more distantly from the axial furrows.

\section{Elrathina athena new species}

Figure 9.1-9.13

Holotype.-MGUH 30914 (Fig. 9.1, 9.2, 9.4, 9.5, 9.9, 9.13). Western side of Henson Gletscher, Lauge Koch Land, North Greenland, middle part of the Ekspedition Bræ Formation, characterized by GGU sample 225501 .

Paratypes.-Western side of Henson Gletscher, GGU sample 225501: five exoskeletons without librigenae (figured specimens under MGUH 30916 and 30917), one incomplete thorax (MGUH 30915), several thoracic segments assigned to the species; western side of Løndal, GGU sample 255720: one exoskeleton without librigenae, three cranidia. Tentatively assigned to E. athena n.sp.: one meraspid cephalon (MGUH 30918).

Diagnosis.-Species of Elrathina with slightly tapering glabella, glabellar front with shallow curvature only, almost subtruncate in the median sector; palpebral lobes small, but not minute, distinctly within the anterior half of the cephalon; eye ridges with gentle curvature; anterior border with rearward swelling that creates distinct rearward extension; anterior border furrow nearly confluent or (rarely) confluent with furrow in front of glabella; anterior branches of facial suture moderately curved in the anterior half of its course; geniculation on thoracic pleurae slightly to distinctly distant to pleural mid-length; pygidium sublenticular in outline; rhachis weakly subdivided, posterior tip almost reaches to posterior margin; surface of test, inclusive of most furrows, glabella, fixigenae, and axial rings, densely covered with minute granules and with moderately large, widely spaced granules.

Description.-The exoskeleton of Elrathina athena n. sp. is similar to that of E. aphrodite n. sp., so the following description focuses on differences between the species.

Cranidium with ratio length to width across palpebral lobes $\sim 0.85$; ratio length to width across posterolateral processes of genae $\sim 0.55$. Glabella tapering forward from widest (tr.) portion at L1 to S4 to $~ 85 \%$ of maximum width; slight constriction across $\mathrm{S} 1$; frontal lobe with low curvature; length variably from $75-85 \%(\mathrm{~N}=7)$ of cephalic length (inclusive occipital ring) in adult and nearly adult individuals, less in juveniles; transverse width of glabella across L1 45-49\% ( $\mathrm{N}=7)$ of transverse cranidial width across center of palpebral lobes. Glabellar furrows shallow and poorly marked near axial furrows; S1 faintly bifurcate, usually a fairly broad depression; S3 very shallow to obsolescent, more or less transverse, disconnected from axial furrows; S4 often obsolescent, more or less transverse. Occipital furrow consists of slightly obliquely backward directed, slightly curved lateral sections and a shallower, nearly straight median section. Occipital ring with backward swinging, steep posterolateral margin; posterior margin more strongly curved in immature specimens; sagittal length in adult specimens $\sim 10 \%$ of cephalic length, up to more than $15 \%$ in juveniles; with short, distinct median spine, the base of which covers more than two-thirds of the breadth of the occipital ring.

Palpebral lobe short, in adult individuals exsag. of 11-15\% $(\mathrm{N}=7)$ of cephalic length (distinctly longer in juveniles); ocular suture in dorsal view a moderately curved line; palpebral furrow merely a change in convexity. Posterior end of eye ridge with bifurcation or trifurcation, which is indistinct on the surface of the test, separated from anterior end of palpebral lobe by shallow depression. Fixigena with transverse width between posterior ends of palpebral lobe and axial furrow 45-50\% $(\mathrm{N}=7)$ of maximum glabellar width in adult individuals, $55-60 \%$ in immature specimens.

Anterior border variably of $11-14 \%(\mathrm{~N}=7)$ of cephalic length on sagittal line; median section of anterior margin weakly curved to almost straight or almost with a concave embayment in dorsal view. Anterior border furrow slightly curving towards glabellar front if the median extension of the anterior border is well developed and then shallower and slightly dorsally raised (Fig. 9.3, 9.7). Preglabellar field narrow. Posterior border furrow moderately wide (exsag.), slightly wider than border for most of its course.

Surface of cranidium, inclusive of most furrows, densely covered with minute granules (Fig. 9.2). Glabella, fixigenae, preocular fields, and posterior border carry larger, widely spaced granules in a roughly bilaterally symmetrical arrangement 

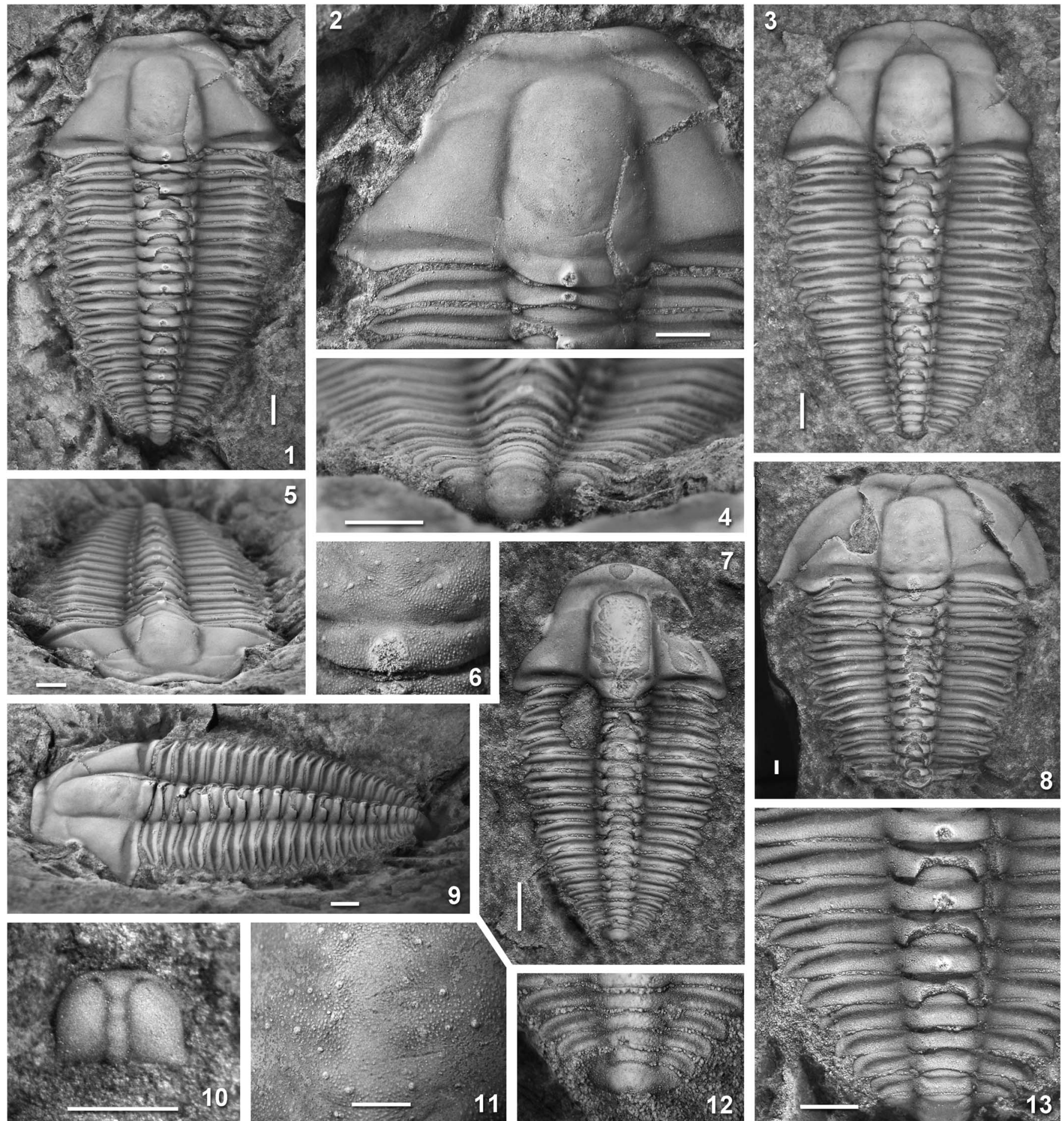

Figure 9. (1-13) Elrathina athena n. sp.; (1, 2, 4, 5, 9, 13) Holotype, MGUH 30914, dorsal carapace without librigenae; (1) dorsal view of entire specimen; (2) close-up of Fig. $9.1 ;(\mathbf{4})$ oblique posterior view of ventrally inclined pygidium; (5) oblique anterior view showing abrupt geniculation of thoracic pleurae and bulbous lateral portions of the rhachis; (9) oblique lateral view revealing slight s-shaped flexion of thorax; (13) posterior thorax, partly exfoliated test exhibits some broad articulating half-rings; (3) Paratype, MGUH 30915, dorsal carapace without librigenae, dorsal view; (6, 8, 11) Paratype, MGUH 30916, dorsal carapace with slightly displaced librigenae and incomplete thorax; (6) close-up of Fig. 9.8, showing minute wrinkles in the occipital furrow and surface ornamentation; (8) dorsal view of entire specimen; (11) central part of glabella with minute granulation and widely spaced larger granules; (7, 12) Paratype, MGUH 30917, dorsal carapace without librigenae; (7) dorsal view of entire specimen; (12) close-up of Fig. 9.7; (10) MGUH 30918, early meraspid. Scale bars $=1 \mathrm{~mm}$.

(Fig. 9.8, 9.11). Preocular fields and anterior border with traces of radial caeca (Fig. 9.2).

Librigena moderately wide, maximum width (perpendicular to maximum length) slightly less than $40 \%$ of oblique maximum length without spine; lateral margin moderately curved. Genal field moderately convex, width between ocular suture and border furrow $\sim 45 \%$ of maximum librigenal width. Lateral border gently convex, width approximately one-third 
maximum librigenal width, of uniform thickness; lateral border furrow a shallow, poorly defined groove; posterior border on librigena short, gently convex, slightly narrower (exsag.) than lateral border; posterior border furrow a shallow, poorly defined groove. Genal spine moderately long, approximately one-fourth librigenal length, slender, defined from lateral border by a gentle abaxial swing of the lateral margin.

\section{Hypostome unknown.}

Thorax of 19 segments in adult individuals of the studied material. Axial rings of segment 3 through 19 of more or less uniform shape (sag. and exsag.) (Fig. 9.1). Transverse width of average axial ring about one-third total width of the segment, growing in relative width to $\sim 45 \%(\mathrm{~N}=5)$ in the posteriormost segment. Greatest width (tr.) at segments 3 to 6 , with slightly but increasingly backward-directed pleurae in the posterior four or five thoracic segments. Pleural furrows moderately broad to broad, form faintly bent, narrow lenticular or faintly s-shaped furrows. Pleural tips extend into short, slightly posterolaterally directed spines that develop from a gently curved anterior margin and an s-shaped distinctive posterior indentation of the pleurae. In anterior view, the pleurae show a distinct geniculation slightly abaxial from the transverse mid-length (Fig. 9.4). First thoracic segment differs in having an axial ring, the anterior margin of which swings clearly backward and defines a medially narrow axial ring. Its pleurae with a distinct angle at a weakly developed fulcral point that fits into the socket on the posterior border of the cephalon (Fig. 9.2). Second thoracic segment has a transitional morphology between segments 1 and 3 of the thorax. Surface of thoracic segment densely covered with minute granules.

Pygidium sublenticular in outline. Rhachis poorly subdivided, well-rounded posterior tip reaches close to the posterior margin. Pleural fields with one pair of broad and indistinct, rearward-curved pleural furrows. Pygidial border and border furrow obsolescent.

Ontogeny.-An early meraspis assigned to Elrathina athena $\mathrm{n}$. sp. (Fig. 9.10) is a subquadrate shield with strongly rounded anterolateral corners and narrowly rounded, slightly extended posterolateral corners. The glabella is well defined and slightly sunken below the strongly convex to slightly inflated genae, extremely slender and faintly tapering from the posterior lobe to L4, and has a distinctly expanded frontal lobe. The glabella is subdivided into five lobes by shallow and broad, transglabellar furrows. The frontal lobe has a triangular outline, but a central globular inflation, and extends into distinct eye ridges that run along the anterior and anterolateral margins and are separated from the cheeks near the frontal lobe by distinct scrobicules. The eye ridges proceed into the barely separated palpebral lobes.

An almost adult, but relatively small specimen (Fig. 9.7) shows a glabella with subparallel sides and a fairly broad anterior border with a less-conspicuous swelling and a relatively broad (sag.) occipital ring.

Etymology.-Named after the Greek goddess of wisdom, courage and justice, Pallas athena; a reference to the 'judgment of Paris'.
Remarks.-Elrathina athena $\mathrm{n}$. sp. is most similar to Elrathina aphrodite $\mathrm{n}$. sp. and thus characterized by similar features that also distinguish it from all other species of the genus, namely by the combination of: (1) the distinct extension of the posterior margin of the anterior border; (2) a pygidium with a wide axis that almost reaches to the posterior margin; and (3) the presence of a fine granulation superimposed by an almost bilaterally symmetrical pattern of widely spaced larger granules.

The rearward extension of the anterior border in Elrathina athena $\mathrm{n}$. sp. produces a narrow or sometimes completely reduced preglabellar field that is also known from one of the paratypes of Elrathina fecunda Deiss, 1939 (Deiss, 1939, pl. 15, fig. 7). The differences to Elrathina aphrodite n. sp. have been disussed under this species above.

Elrathina hera n. sp., which co-occurs with E. athena n. sp., is distinguished by its more clearly tapering glabella, an anterior border with only a slight to moderate median swelling and thus a moderately broad (sag.) preglabellar field, palpebral lobes in a slightly more anterior position, a broader pygidium with an axis of moderate width as normal for the genus, and two furrows on the pleural areas, and E. hera n. sp. lacks the distinct prosopon of granules. In addition, the geniculation of the thoracic pleurae tends to be located more distantly from the axial furrows.

\section{Elrathina hera new species \\ Figure 10.1-10.20}

Holotype.-MGUH 30919 (Fig. 10.1). Western side of Løndal, Lauge Koch Land, North Greenland, middle part of the Ekspedition Bræ Formation, GGU sample 255720.

Paratypes.-Western side of Henson Gletscher, Lauge Koch Land, GGU sample 225501: two exoskeletons without librigenae (MGUH 30921 and 30931), one dorsal carapace with displaced librigenae (MGUH 30923); two cranidia (figured specimen under MGUH 30930); western side of Løndal, GGU sample 255720: seven carapaces without librigenae (figured specimens under MGUH 30920, 30922, and 30925), one librigena (MGUH 30927); two partial thoraces (MGUH 30924); 15 cranidia (figured specimens under MGUH 30926, 30928, 30929, 30932, and 30944). Tentatively assigned to Elrathina hera n. sp.: single meraspid cephalon (MGUH 30900).

Diagnosis.-Species of Elrathina with slightly tapering glabella, glabellar front with shallow curvature only, almost subtruncate in the median sector; palpebral lobes small to minute, distinctly anterior to the cephalon's half; eye ridges with gentle curvature; anterior border with faint swelling that creates a slight rearward swing of anterior border furrow; preglabellar field moderately wide; anterior branches of facial suture moderately curved in the anterior half of its course; librigenae with short genal spine; thorax of 18 segments; geniculation on pleurae distinctly distant to pleural mid-length and at almost two-thirds distant in the anterior part of the thorax; pygidium sublenticular in outline; rhachis moderately wide, weakly subdivided, its posterior close to posterior margin; pleural areas with two faint furrows; surface of test smooth or punctate. 

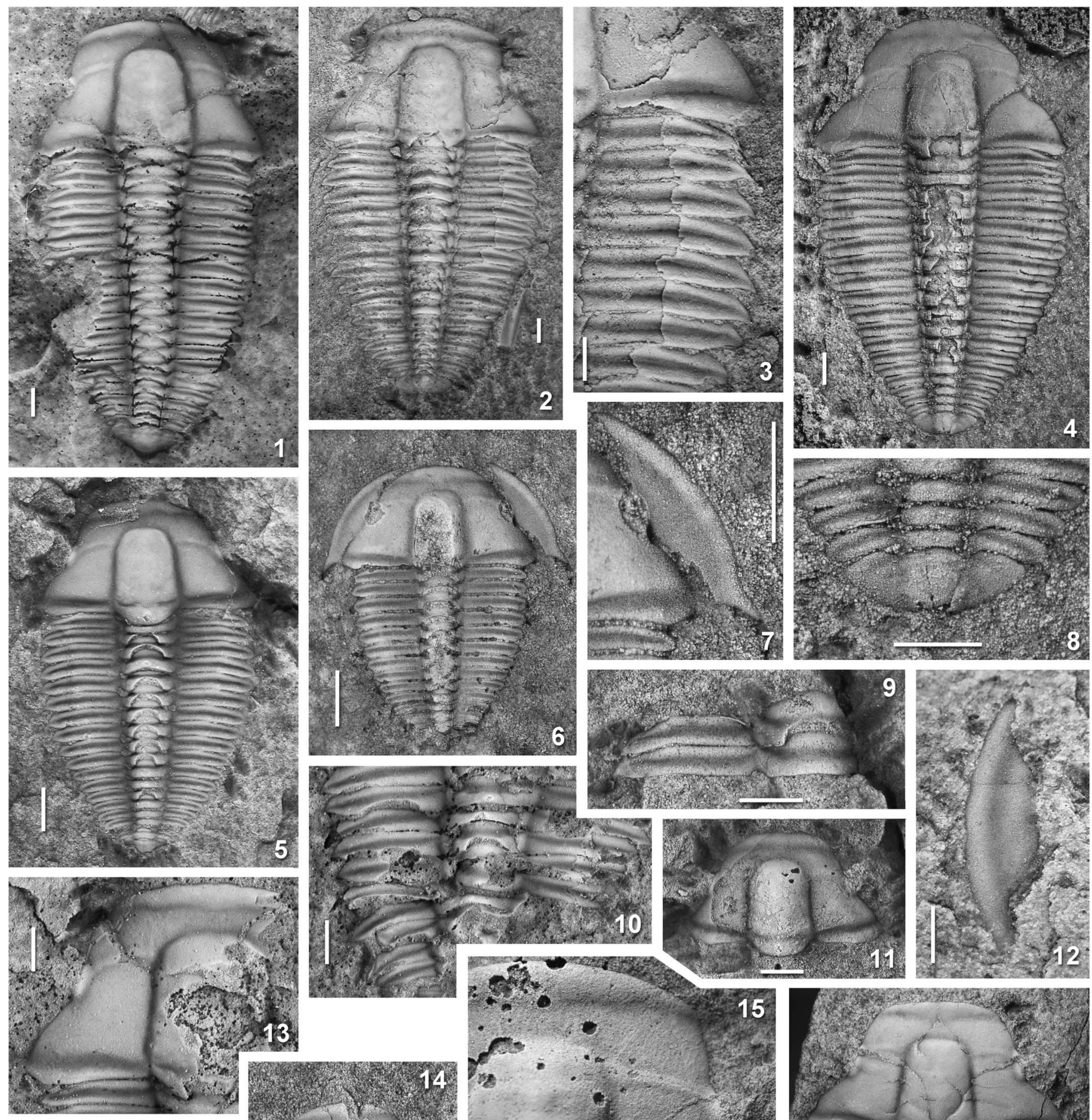

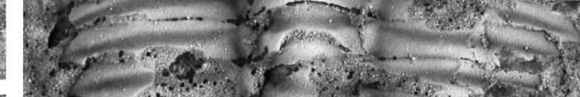
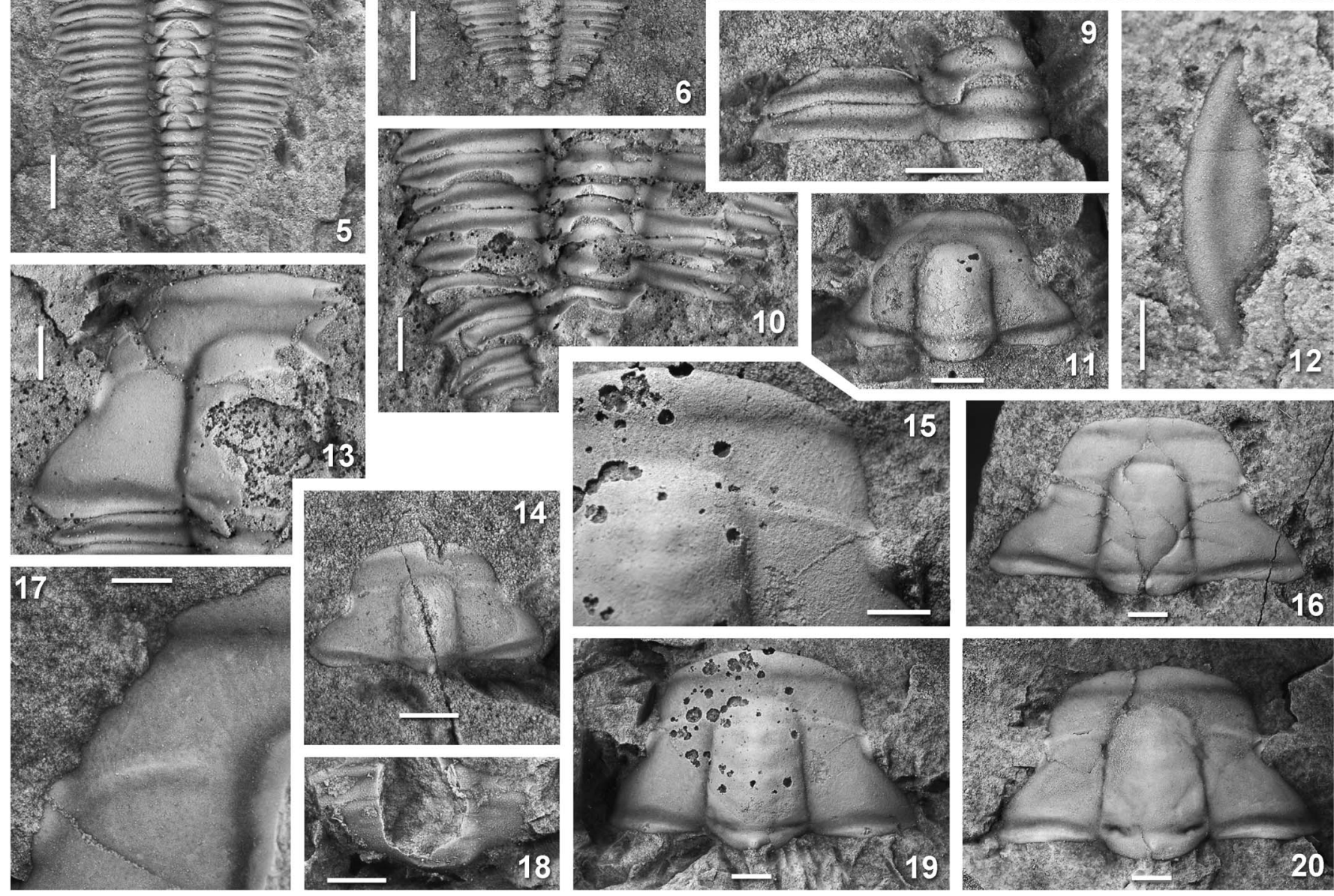

11

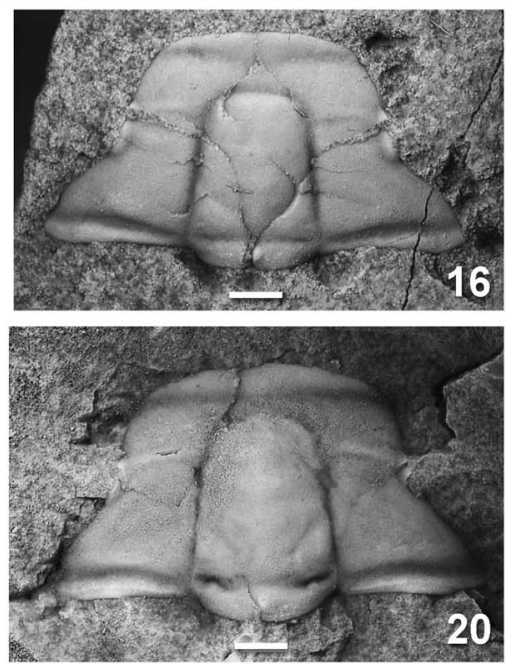


Description.-Cranidium subtrapezoidal in outline; ratio length to width across palpebral lobes $~ 0.8$; ratio length to width across posterolateral processes of genae $\sim 0.60-0.65(\mathrm{~N}=11)$.

Glabella moderately convex, slightly tapering forward from widest (tr.) portion at $\mathrm{L} 1$ to $\mathrm{S} 4$ to $80-85 \%(\mathrm{~N}=11)$ of maximum width; slight constriction across $\mathrm{S} 2$; front with low curvature, medially almost flat in large individuals; length variably from $74-79 \%(\mathrm{~N}=11)$ of cephalic length (inclusive occipital ring) in adult and nearly adult individuals, slightly less in juveniles; transverse width across L1 42-48\% ( $\mathrm{N}=11)$ of cranidial width across center of palpebral lobes, less than $40 \%$ in juveniles. Four pairs of glabellar furrows, all shallow and poorly marked near axial furrows; S1 usually a fairly broad depression directed obliquely backward; S2 a somewhat backward-directed longitudinal depression; S3 a slightly backward-directed ovate depression, disconnected from axial furrows; S4 an often obsolescent, transversely elliptical depression. Occipital furrow consists of narrow lateral sections and a shallower and broader straight median section. Occipital ring of adult specimens strongly convex in sagittal section; with backward-swinging, steep posterolateral margin; posterior margin more strongly curved in immature specimens; sagittal length in adult specimens $\sim 12 \%$ of cephalic length, up to more than $15 \%$ in juveniles; with broad median thorn.

Axial furrows moderately deep to shallow laterally, narrower in front of the glabella. Palpebral lobe short, in adult individuals of $15-20 \%(\mathrm{~N}=11)$ of cephalic length (longer in juveniles), somewhat oblique to axis, anterior end in transverse line with L3, posterior end about in transverse line with S2; prominent, developed as a distinctly upturned longitudinal bulge that rises from palpebral furrow; sometimes adaxially merged with a low ridge that originates from the posterior end of the eye ridge; ocular suture a moderately curved line in dorsal view; palpebral furrow a shallow, poorly defined longitudinal depression that proceeds into a shallow depression separating the eye ridge from the palpebral lobe. Eye ridge a low to moderately elevated, curved lobe on test, directed slightly forward from palpebral lobe, nearly normal to axis close to axial furrow that is met opposite S4; eye ridge bifurcated at internal molds (Fig. 10.15); adaxial end crosses axial furrow, internal molds show that the anterior part proceeds into a parafrontal band fused with the frontal lobe (Fig. 10.15).

Fixigena gently convex, moderately wide (tr.), transverse width between posterior ends of palpebral lobe and axial furrow 53-60\% $(\mathrm{N}=11)$ of maximum glabellar width in adult individuals, $60-68 \%$ in immature specimens. Posterior area of fixigena extends into long posterolateral projection.

Anterior border gently convex, moderately broad, slightly increasing in breadth from suture to sagittal line and with weak median rearward swelling; $12-15 \%(\mathrm{~N}=9)$ of cephalic length on sagittal line; median section of anterior margin gently to moderately curved. Anterior border furrow shallow, tends to show weak bends on faint swellings medially or sometimes in front of the preglabellar fields as well (e.g., Fig. 10.1, 10.2). Preglabellar field relatively narrow (sag.), $\sim 10 \%$ of cephalic length, only slightly narrower than border anterior to it. Genal fields moderately to distinctly convex, distinctively sloping ventrally towards anterior border furrow. Anterior branches of suture with convergent anterior sections, distinctly curved inward when meeting anterior border furrow. Posterior border narrow (exsag.) near axial furrow, with gentle posterolateral curvature, slightly increasing in breadth (exsag.) up to a distinct rearward extension about two-thirds distance from posterolateral tips. Posterior border furrow moderately wide (exsag.), increasing in width from axial furrow, slightly wider than border for most of its course, shallower towards the posterior branch of suture.

Surface of cranidium smooth except for faint radial and branched caeca on fixigenae, preocular fields, and anterior border; more conspicuous on internal molds (Fig. 10.19).

Librigena moderately wide, maximum width (perpendicular to maximum length) less than $40 \%$ of oblique maximum length without spine; lateral margin moderately curved. Genal field gently convex, width between ocular suture and border furrow more than half of maximum librigenal width. Lateral border gently convex, of uniform thickness, width $\sim 40 \%$ of maximum librigenal width; lateral border furrow a broad, shallow, poorly defined groove; posterior border on librigena very short, slightly narrower (exsag.) than lateral border. Genal spine moderately long, approximately one-fourth librigenal length, lateral margin with gentle abaxial swing between lateral border and abaxial border of genal spine.

\section{Hypostome unknown.}

Thorax of 18 segments in adult individuals of the studied material (Fig. 10.1, 10.2, 10.4). Axial rings of segment 3 through 19 of more or less uniform shape (sag. and exsag.), length and width reduced progressively posteriorly. Transverse width of average axial ring less than $30 \%$ of total width of the segment, increasing in relative width to about one-third in the posteriormost segment. Narrow articulating furrow with apodemal pit distally. Each ring with lateral inflations indicating attachment sites of ventral muscles. Greatest width (tr.) at segments 4 to 6, decreasing in width (tr.) towards posterior, with increasingly backwarddirected pleurae in the posterior four or five thoracic segments. Pleural furrows moderately broad to broad (exsag.), forming nearly straight or slightly s-shaped, faintly oblique furrows with faintly broader median section, with slightly better-defined anterior margin, fading near pleural tips. Pleural tips extend into

Figure 10. Elrathina hera n. sp.; (1) MGUH 30919, holotype, dorsal carapace without librigenae; (2, 3) Paratype, MGUH 30920, dorsal carapace without librigenae; (2) entire specimen; (3) close-up of Fig 10.2; (4, 8) Paratype, MGUH 30921, dorsal carapace without librigenae; (4) entire specimen; (8) close-up of Fig. 10.4; (5) Paratype, MGUH 30922, dorsal carapace without librigenae; (6, 7) Paratype, MGUH 30923, dorsal carapace with slightly displaced librigenae; (6) entire specimen; (7) close-up of Fig. 10.6; (9) Paratype, MGUH 30924, two articulated thoracic segments, slightly inclined; (10, 13) Paratype, MGUH 30925, incomplete carapace; (10) detail of thorax; (13) cranidium and anterior thoracic segments, with slight swelling of anterior border; (11) Paratype, MGUH 30926, immature cranidium; (12) Paratype, MGUH 30927, isolated librigena; (14) Paratype, MGUH 30928, immature cranidium; (15, 19) Paratype, MGUH 30929, cranidium, internal mold; (15) caeca on preglabellar field and preocular field and bifurcated eye ridge; (19) entire specimen; (16) Paratype, MGUH 30930, cranidium; note course of fractures created by dorsoventral compaction; $(\mathbf{1 7}, \mathbf{1 8})$ Paratype, MGUH 30931, carapace without librigenae, internal mold; $(\mathbf{1 7})$ cranidium with bifurcated eye-ridge and triplicit connection with palpebral lobe; (18) incomplete pygidium and posterior thoracic segment; (20) Paratype, MGUH 30932, cranidium with fractures. Dorsal views. Scale bars $=1 \mathrm{~mm}$. 
short, thorn-like spines that develop from a gently curved anterior margin and an s-shaped posterior indentation of the pleurae. In anterior view, pleurae show a distinct geniculation slightly abaxial of pleural mid-length, which corresponds with the articulation of adjacent segments by means of a fulcral point. The type of articulation and the inclination is particularly well visible in two articulated and slightly inclined segments (Fig. 10.9). Inclination led to an overlap of the distant pleural portions so that the anterior flanks of these have an almost flat although narrow articulating facet, whereas the posterior margin of the distal pleura turns slightly forward to allow a limited overlap of adjacent segments during inclination of the segments. The same specimen and a thorax fossilized in a state of decay (Fig. 10.10) show relatively broad (sag.) articulating half-rings to allow a fairly strong inclination of adjacent segments at more than $15^{\circ}$. First thoracic segment differs in having an axial ring, the anterior margin of which swings clearly backward to allow a distinct dorsal flexure of the cephalon against the thorax. Its pleurae are straight in the proximal sector, but show a distinct angle at a weakly developed fulcral point that fits into the socket on the posterior border of the cephalon; the distal part of its pleura is reduced in size and has a distinctly backward-directed anterior margin, and an obliquely ventrally articulating facet, so that the distal portion has a narrow triangular outline in dorsal view (Fig. 10.3). Second thoracic segment has a transitional morphology between segment 1 and 3 of the thorax. Surface of thoracic segments smooth.

Pygidium sublenticular in outline. Rhachis a wide, poorly subdivided, moderately convex axis with well-rounded posterior tip that reaches to the posterior margin (Fig. 10.8); width at anterior ring $\sim 40 \%$ of maximum pygidial width; one or two axial rings marked by broad and obscure, transverse furrows. Pleural fields with one pair of broad and indistinct, slightly curved pleural furrows, occasional with second furrow near axial furrow. Pygidial border and border furrow obsolescent. Lateral and posterior margins entire.

Etymology.-Named after the Greek goddess of women and marriage, Hera; a reference to the 'judgment of Paris' because the common occurrence of three similar species.

Ontogeny. - The studied material lacks larval stages that can be assigned confidently to Elrathina hera n. sp., but includes a number of immature cranidia and two almost complete exoskeletons. The immature or at least small cranidia (Fig. 10.6, $10.11,10.14)$ are characterized by a glabella with subparallel sides and a more clearly convex anterior border without, or with less-conspicuous swelling, as in the larger individuals.
In addition, they have wider (tr.) fixigenae and more anteriorly located palpebral lobes.

A juvenile carapace with slightly displaced librigenae and without pygidium (Fig. 10.6) has a thorax of probably 13 segments, the pleurae of which have their geniculation in a distinctly distal position and a cranidium that clearly expands laterally beyond the pleural tips in the thorax.

Remarks.-Elrathina hera n. sp. is characterized by having a slight median swelling of the anterior border, a moderately broad preglabellar field, a slightly tapering glabella, and a small to moderately long librigenal spine.

Comparisons with the contemporaneous species Elrathina aphrodite n. sp. and E. athena n. sp. have been discussed above and include particularly the non-granulate surface of the test, the more clearly tapering glabella, an anterior border with only a slight median swelling and thus a moderately broad (sag.) preglabellar field, slightly shorter palpebral lobes in a slightly more anterior position, generally more distinctly forwarddirected eye ridges, and a narrower pygidial rhachis. In addition, the geniculation of the thoracic pleurae tends to be located more distantly from the axial furrows.

Species similar to Elrathina hera n. sp. include E. parallela, E. spinifera, E. convexa, E. fecunda, E. hybrida, E. lickensis, and E. cordillerae. Elrathina convexa, E. fecunda, E. hybrida, and E. lickensis lack the medial swelling of the anterior border. In addition, E. convexa has a narrower preglabellar field, but this species shares the palpebral lobes in a distinctly anterior position. Elrathina hybrida and E. lickensis have a more strongly tapering glabella, which is particularly broad in E. lickensis. Elrathina hybrida also shows slightly broader genae.

Except for the medial swelling, the holotype of E. fecunda shows greatest similarity with E. hera $\mathrm{n}$. sp. Further differences can be seen in the slightly more abaxially located geniculation of the thoracic segments and an apparently more tapering glabella. Unfortunately, details of the pygidial morphology and the librigenae are unknown.

Elrathina spinifera Rasetti, 1951 is very similar but is known only from cranidia. These cranidia are differentiated from those of $E$. hera n. sp. by slightly narrower fixigenae, palpebral lobes in a slightly less-anterior position, and a slightly more-bulging anterior border. In addition, E. spinifera appears to have had a more prominent occipital node or even thorn.

Elrathina parallela Rasetti, 1951 is based on slightly distorted material and thus difficult to precisely characterize. The palpebral lobes in E. parallela are also not quite in such an anterior position as those in E. hera n. sp., and they are also slightly longer. The geniculation of the thoracic pleurae in E. parallela is situated

\footnotetext{
Figure 11. Elrathia groenlandica n. sp.; (1) Holotype, MGUH 30933, cranidium; (2, 17) Paratype, MGUH 30934, incomplete cranidium; (2) close-up of Fig. 11.1 showing muscle scars on the glabella and eye ridge; (17) occipital ring with granulation and acute occipital node; (3) Paratype, MGUH 30935, early meraspid cranidium; (4) Paratypes, MGUH 30934 and 30936, two incomplete cranidia; (5, 7, 11) Paratype, MGUH 30937, incomplete cranidium; (5) dorsal view; (7) close-up of Fig. 11.5, with muscle scars on the glabella, radial caeca on frontal area, bifid eye ridge, and punctate surface of the internal mold; (11) posterior border with discrete crestal ridge; $(\mathbf{6}, \mathbf{8 , 1 0})$ Paratype, MGUH 30938, incomplete cranidium; (6) lateral view; (8) dorsal view; (10) muscle scar pattern on the glabella; (9) Holotype, MGUH 30933, and paratype, MGUH 30939, cranidium and thorax with attached pygidium; scale bar = 5 mm; (12) Paratype; MGUH 30940 and MGUH 30941, cranidium and thoracic ring; (13) Paratype, MGUH 30942, dorsal carapax without librigenae, dorsal view; scale bar = 5 mm. (14) Paratype, MGUH 30943, meraspid cranidium, dorsal view; (15) Paratype, MGUH 30944, immature cranidium, dorsal view; (16, 19) Paratype, MGUH 30945, pygidium, dorsal and posterior views; (18) Paratype, MGUH 30946, pygidium with two articulated thoracic segments, dorsal view; (20) Paratype, MGUH 30939, thorax with articulated pygidium, with anterior pleurae of pygidium developed as 'freshly fused' tergites; (21) Paratype, MGUH 30948, incomplete pygidium, dorsal view. Scale bars $=1 \mathrm{~mm}$, except for Fig. 11.9 and 11.13.
} 

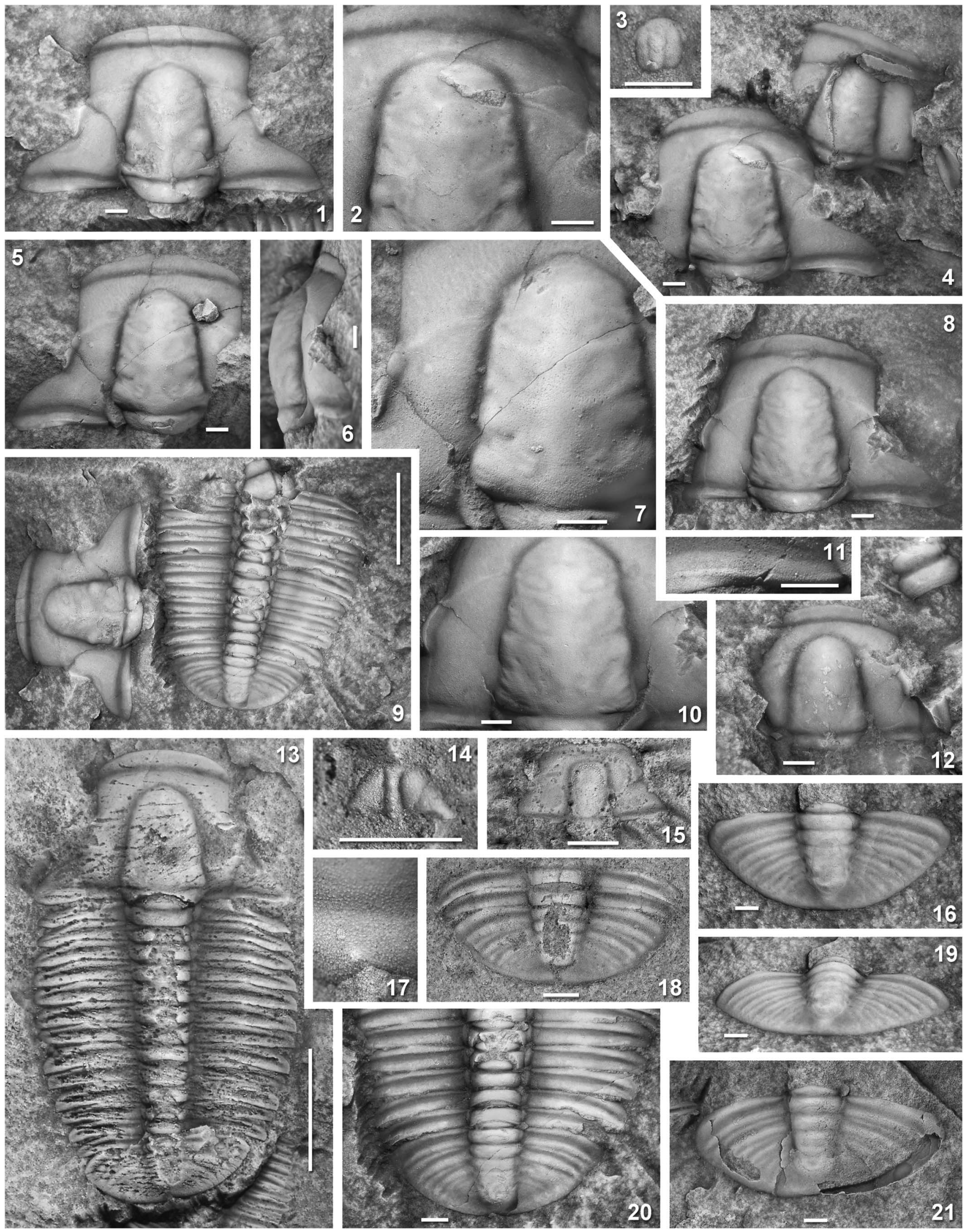

10
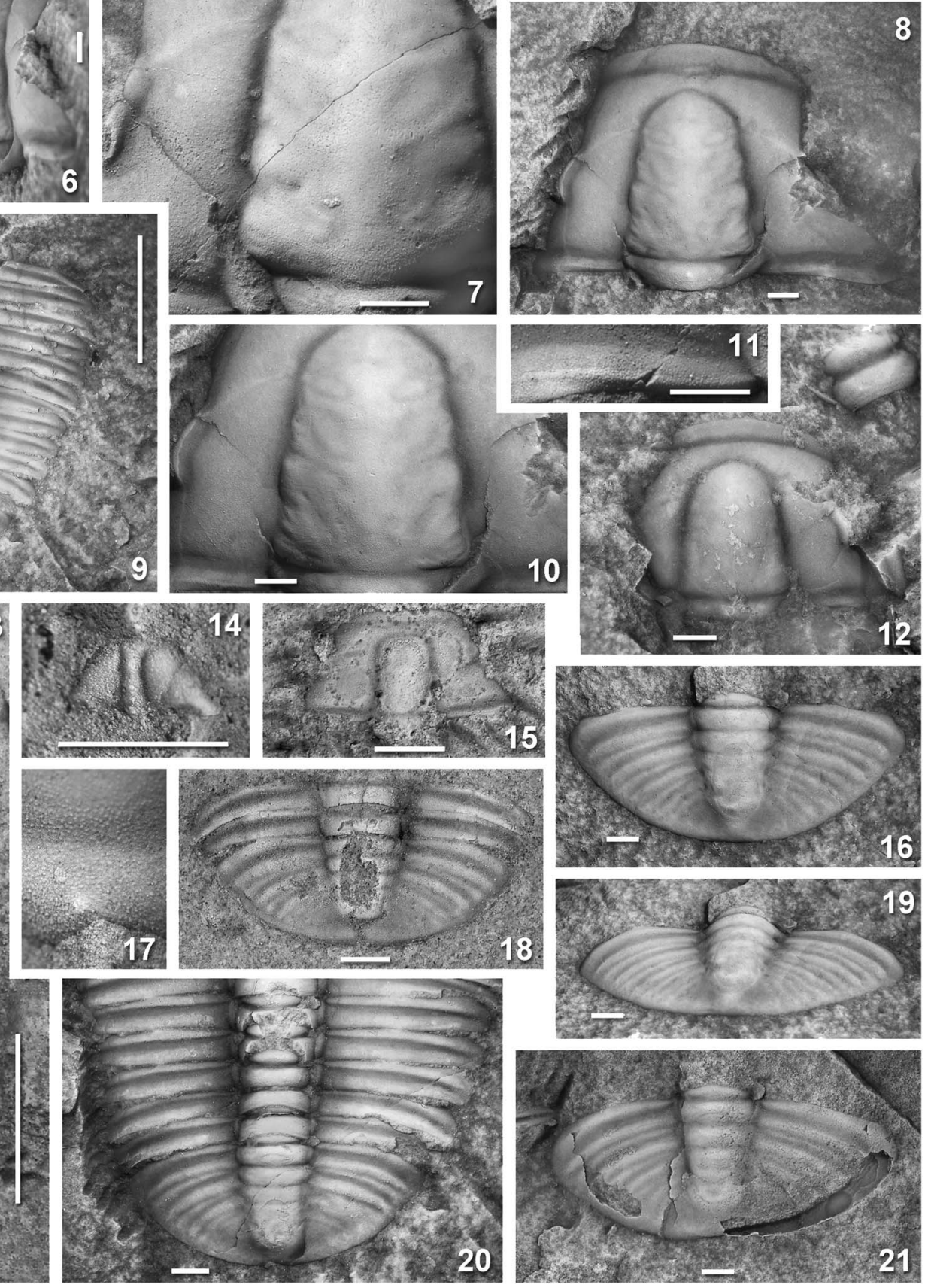
only slightly abaxially from the pleural midlength and thus not as distant from the axis as in the anterior part of the thorax in E. hera n. sp. In addition, the pleural tips in E. parallela are somewhat truncated rather than acutely triangular.

\section{Genus Elrathia Walcott, 1924}

Type species.-Conocoryphe (Conocephalites) kingii Meek, 1870, p. 63; from the Wheeler Formation, middle Cambrian, Utah, U.S.A.

\section{Elrathia groenlandica new species. Figures 11.1-11.21, 12}

Holotype.-MGUH 30933 (Fig. 11.1). Western side of Henson Gletscher, Lauge Koch Land, North Greenland, middle part of the Ekspedition Bræ Formation, GGU sample 225501.

Paratypes.-Western side of Henson Gletscher, Lauge Koch Land, GGU sample 225501: seven cranidia and cranidial fragments (figured specimens under MGUH 30934, 30936, 30937, 30938, 30935, and 30940), three thoracic segments (figured specimen under MGUH 30941), thorax with articulated pygidium (MGUH 30939), and one pygidium (under MGUH 30945); western side of Løndal, GGU sample 255720: exoskeleton without librigenae (under MGUH 30934), six cranidia and cranidial fragments (figured specimens under MGUH 30943 and 30944), two thoracic pleurae, one pygidium (MGUH 30948), one pygidium with posteriormost thoracic segments (MGUH 30946).

Diagnosis. - Adult individuals with glabella approximately threequarters of cephalic length, distinctly tapering to $\sim 70 \%$ of maximum width, with almost straight sides and a rounded to subacute front; anterior border moderately wide (sag.) and moderately convex, slightly narrower than preglabellar field in front of the glabella; anterior border furrow with a small and low lenticular median swelling; eye ridges distinctly oblique, palpebral lobes of $\sim 20 \%$ of cephalic length. Thorax typically of 13 segments in adult individuals. Pygidium relatively large, pygidial rhachis with five rings; pygidial border furrow fairly well impressed.

Description.-Cranidium subtrapezoidal in outline, with strongly extending posterolateral portions and subparallel anterior branches of suture. Ratio length to width $\sim 0.60$.

Glabella transversely moderately convex, lateral profile gently convex in the posterior half, progressively sloping towards anterior; more or less equally tapering forward from occipital furrow to $\mathrm{S} 4$ to $\sim 70 \%$ of maximum width; frontal lobe with rounded anterolateral corners and a rounded median portion, which tends to mimic a faintly triangular front due to an enlarged shallow parafrontal band (Fig. 11.7); length 74-77\% $(\mathrm{N}=8)$ of cephalic length (inclusive occipital ring), transverse width across L1 35-37\% ( $\mathrm{N}=8)$ of transverse cranidial width across posterior wings and slightly more than $50 \%$ of distance across posterior tips of palpebral lobes in undeformed specimens. Four pairs of glabellar furrows, moderately well impressed near axial furrows, progressively less well impressed from S1 through S4 and distinctly fading towards midline; S1 directed strongly backward from axial furrows and gently curved, shallow for most distance; S2 backward directed, shallow; S3 shallow, slightly backward directed; S4 faint, more or less normal to axis, but with weak curvature. All glabellar furrows show a distinct broadening on the axis, forming large leaf-shaped areas that indicated the anchorage sites of glabellar muscles. These attachment areas are divided into a faintly convex central part, representing the actual anchorage site, surrounded by a very shallow elliptical groove (Fig. 11.7). Occipital furrow with backward-directed narrow and deep lateral sections and a shallower, nearly straight median section. Occipital ring with backward-swinging, steep posterolateral margin and a median portion with a shallow curvature; lateral portions narrow; sagittal length $~ 12-13 \%$ cephalic length; with low median node.

Axial furrows well incised and moderately deep laterally, shallower in front of the glabella. Palpebral lobe fairly short, in adult individuals exsag. of $18-23 \%(\mathrm{~N}=8)$ cephalic length (slightly longer in juveniles), oblique to axis, anterior end in transverse line with S3, posterior end about in transverse line with the posterior rim of $\mathrm{L} 2$ or with $\mathrm{S} 1$; palpebral lobe prominent, either developed as a slightly curved torus or nearly a longitudinal segment of an ellipse, rises steeply from cheek, defined by a distinct and narrow palpebral furrow. Eye ridge forms shallow elevated lobes directed inward and forward to meet axial furrow opposite immediately anterior to S4; bifurcated adaxially on internal molds, and occasionally with faint threads near posterior end of palpebral lobe; anterior branch with faint continuation to frontal lobe across deep axial furrow. Fixigenae gently convex, transverse width between posterior ends of palpebral lobe and axial furrow $41-44 \%$ $(\mathrm{N}=8)$ of maximum glabellar width. Posterior area of fixigena extends into wing-like posterolateral projection (Fig. 11.1).

Anterior border gently to moderately convex, moderately broad, growing from the suture to the sagittal line to about double breadth, variably of $11-14 \%(\mathrm{~N}=8)$ of cephalic length; anterior margin with gentle curvature in dorsal view. Anterior border furrow with a small and low, but fairly distinct lenticular median swelling (e.g., Fig. 11.8). Preglabellar field sagittally slightly wider than anterior border, gently convex in front of the glabella. Genal fields gently to distinctly convex, sloping towards anterior border furrow. Anterior branch of suture subparallel from anterior ends of eyes, then curving inward in a strong curvature when meeting the anterior border. Posterior border fairly narrow (exsag.) near axial furrow, directed posterolaterally with gentle curvature and growing in breadth up to a fulcral point about $40 \%$ of distance from posterolateral tips. Posterior border furrow moderately wide (exsag.), moderate to deep, slightly shallower adaxially and near posterior branches of suture.

Surface of cranidium densely covered with small granules (Fig. 11.17) except for smooth axial and border furrows. Internal mold with distinct radial and branched caeca on preglabellar field and preocular areas and low, indistinct caeca on fixigenae, as well as fine punctae.

\section{Librigena unknown.}

Thorax of 13 segments in the present material. Axial rings of segment 3 to 13 of more or less uniform shape (sag. and exsag.), length and width reduced progressively posteriorly. 
Transverse width of axial ring slightly less than $25 \%$ of overall width of the segment. Narrow (sag. and exsag.) articulating furrow with faint apodemal pit distally. Each ring has a lateral inflation indicating attachment sites of ventral muscles. Greatest width (tr.) at segments 4 or 5 , decreasing progressively in width (tr.), with slightly backwardly directed pleurae in the posterior fourth of the thorax. Pleural furrows moderately wide, more or less straight, slightly oblique to transverse axis, fading short distance from pleural tips. Pleural ends form asymmetrical short spines developed from a gently rounded anterior margin and an s-shaped posterior indentation of the pleurae. In anterior view, pleurae show a distinct geniculation at about transverse midlength, which corresponds with the articulation of adjacent segments by means of a fulcral point. As a result, the anterior flanks of the distant pleural portions have an almost flat articulating facet whereas the posterior margin of the distal pleura turns slightly forward to allow overlap of adjacent segments during inclination of the segments. First thoracic segment differs in having an axial ring, the anterior margin of which swings slightly backward to allow a slight dorsal flexure of the cephalon against the thorax. Its pleurae have a particularly well-developed fulcral point to fit into the socket on the posterior border of the cephalon; distal part of its pleura with a distinctly backward-directed anterior margin and a distinct, oblique articulating facet. This configuration is repeated in a less-distinct manner in the second thoracic segment.

Pygidium subsemielliptical in outline, length $\sim 45 \%$ of maximum width (tr.). Axis of $\sim 80-85 \%(\mathrm{~N}=4)$ of pygidial length, tapering backward, width (tr.) at anterior ring 25-28\% $(\mathrm{N}=4)$ of maximum pygidial width; composed of four axial rings and a terminal axial piece. Axial rings with lateral swellings that mark anchorage sites of ventral muscles. Articulating half-ring slightly narrower (tr.) than anterior axial ring of the rhachis, slender (sag.), but distinctly convex. Posterior end of axis extends into moderately well-developed plectrum. Pleural fields with approximately five pairs of fairly broad pleural furrows, which traverse the segments slightly obliquely and terminate some distance from pygidial margin; with shallow and fairly low interpleural furrows. Pygidial border and border furrow obsolescent. Lateral margins entire, more or less equally curved; posterior margin with faint indentation posterior to axis.

Ontogeny.-A few larval remains and immature specimens are tentatively assigned to Elrathia groenlandica n.sp. The smallest specimen is probably an early meraspis (Fig. 11.3) preserved as a strongly convex, suboval shield with a subtruncate posterior margin. The imperfectly preserved specimen shows a poorly defined glabella with subparallel sides bounded by increasingly shallowing axial furrows so that the glabellar front is not recognizable. Strong and extended palpebral lobes are visible along the anterolateral edges of the cephalon and appear to extend into eye ridges along the cephalic margin. A later meraspis (Fig. 11.14) has a slender glabella with a distinctly expanding front that reaches to the anterior border with slightly forward-tapering posterior two-thirds that are traversed by faint and shallow furrows. A narrow (sag.) and slender occipital ring is defined by a narrow, but relatively well-impressed transverse occipital furrow. Palpebral lobes are incompletely visible and located along the anterolateral margin. The posterolateral corners are extended into elevated and blunt processes.

Late immature cranidia indicate development from a glabella with subparallel or slightly tapering sides with a flattened front and broad genae (Fig. 11.15) to specimens in which the tapering glabella has a parabolic outline and a narrowly rounded front (Fig. 11.12) in combination with a rearward movement and a distinct growth in length of the palpebral lobes and a stronger rearward direction of the eye ridges.

Cephalic musculature.-A few specimens of Elrathia groenlandica n. sp. from GGU sample 225501 show well-preserved muscle scars on the glabella. The pattern of muscle attachment sites varies to some degree, but is characterized by four pairs of larger, suboval to kidney-shaped muscle scars, which coincide more or less with the position of the lateral glabellar furrows S1 through S4. Two pairs of smaller, suboval muscle scars can be detected on L1 plus two additional pairs of extended elliptical pairs close to the axial furrow. The occipital ring has traces that may reflect additional pairs of muscle imprints (e.g., Fig. 11.1, $11.2,11.7,11.10)$. All these belong to so-called 'muscle scar group 1' (sensu Campbell, 1975) and are manifestations of the same kind of musculature group interpreted to pertain to the cephalic limbs.

In addition, a smaller pair of elliptical scars is located in the posterior part of the frontal lobe. According to its anterior location, this smaller and less clearly manifested pair of scars could be interpreted either as characterizing soft tissue insertion sites ('auxiliary impressions,' sensu Eldredge, 1971, or 'muscle scar group 2 and 3,' respectively, of Campbell, 1975). Alternatively, the small pair of muscles on the frontal lobe can be interpreted as the attachment site for the antennae (Lerosey-Aubril et al., 2011) (Fig. 12).

There is no indication of the pair of large preoccipital scars seen in most other Cambrian trilobites (e.g., Rudolph, 1994). Nevertheless, the relatively anterior position of the lateral glabellar furrows S1 may have given risen to compartmentalized scars, in which case the two small and less-well-developed marks close to the occipital furrow and those close to the axial furrow on L1 may be satellites of the first big muscle attachment along S1. The large scars in a relatively adaxial position and distant from the axial furrow are probably insertion loci for the four pairs of cephalic biramous limbs.

Etymology.-From Grønland, the Danish name of Greenland; a reference to the occurrence of the species.

Remarks.-Elrathia Walcott, 1924 has long served as a wastebasket for ptychoparioid species without eye-catching special characters. Robison (1964) revised the generic concept and restricted Elrathia to include only E. kingii (Meek, 1870), the the type species, E. alabamensis Resser, 1938, and E. georgiensis Resser, 1937b (Fig. 4.3), to which he added the new species E. marjumi Robison, 1964 and E. alapyge Robison, 1964, both from the Wheeler Formation of Utah. He referred Chancia rasettii Shaw, 1957 tentatively to the genus. Additional species are Elrathia alaskensis Palmer, 1968 from the middle 


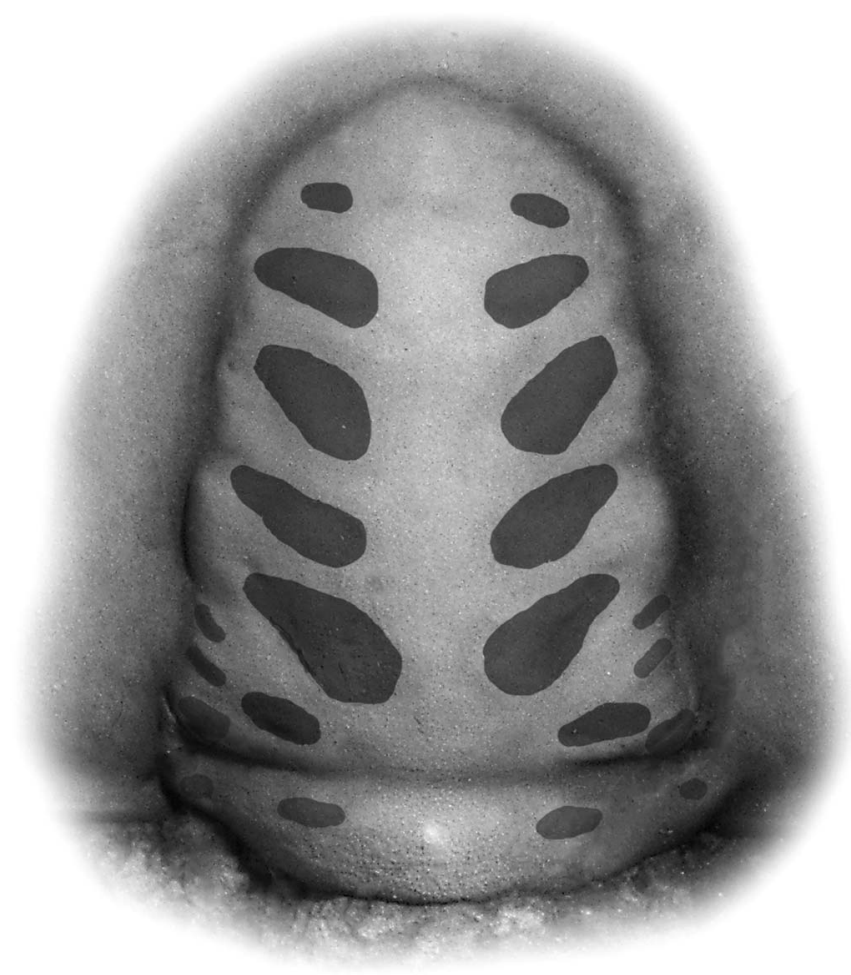

Figure 12. Elrathia groenlandica n. sp. Reconstruction of the muscle scar pattern seen on the glabella.

Cambrian-1 of East-Central Alaska, and E. omega Robison, 1988 from the Holm Dal Formation of North Greenland.

Elrathia groenlandica n. sp. from North Greenland is distinguished from almost all of the established species by a slightly longer glabella and, consequently, more strongly oblique eye ridges. Elrathia kingi has a similarly narrow and low anterior border and a rather slender glabella, but is distinguished from E. groenlandica n. sp. by a transversely narrower occipital ring, slightly longer palpebral lobes, a distinctively wider preglabellar field, a relatively larger pygidium compared with the thorax, five rather than four rings in the pygidial rhachis, and a wider and more clearly impressed pygidial border furrow.

Elrathia marjumi, also described from the Holm Dal Formation of North Greenland (Robison, 1988), has a distinctively wider axis, well-curved glabellar sides, a prominent anterior cephalic border, a thorax of usually 12 rather than 13 segments, a pygidial rhachis with five rings and a short terminal piece, no medial notch that connects the rhachis with the pygidial margin, and the individuals have a finely granular surface of the carapace.

Elrathia alapyge has a distinctively wider axis, well-curved glabellar sides, a prominent anterior cephalic border, a sagittally broader preglabellar field, a thorax composed of 15 segments, the eponymous broad and shallow indentation of the posterior pygidial margin, a pygidial rhachis with only three or four rings, and sometimes a few scattered coarse granules on the surface of the test.

Elrathia omega from the Holm Dal Formation of North Greenland is clearly distinguished by a comparatively shorter (sag.) and more tapering glabella with branched S2, an accordingly wider preglabellar field, a fairly narrow anterior border, symmetrical slight inflections of the anterior border furrow, slightly narrower fixigenae, a thorax composed of
14 segments, and a pygidium with a shorter plectrum that leads to a shallow indentation of the posterior pygidial margin (see Robison, 1988, fig. 26).

Elrathia alaskensis from the Bolaspidella Zone of the Yukon River area, Alaska, is the only species of Elrathia that has a similarly long and equally tapering glabella with also a slightly triangular front. It is distinguished by a slightly broader anterior border and a well-incised anterior border furrow, distinctively longer palpebral lobes, a more lenticularly transverse outline of the pygidium that lacks a clear plectrum, and a finely granulose surface of the test (Palmer, 1968, pl. 5, figs. 10-13). It is noteworthy that the cranidia of Modocia transversa Palmer, 1968 from a nearby collection are only clearly distinguished from those of E. alaskensis by the stronger adaxial curvature of the suture, which cuts the anterior border to create a more luniform anterior border (Palmer, 1968, pl. 5, figs. 2, 5).

Rasetti (1963) described a number of species from limestone boulders of the Lévis Conglomerate of Quebec, which he placed under Elrathia, two of them tentatively. Of these, Elrathia gaspensis appears to be well placed, but is easily distinguished from E. groenlandica n. sp. by a broader glabella with distinctively curved sides, a shorter preglabellar field, a broader and more elevated anterior cephalic border, longer palpebral lobes, a wider (tr.) and longer pygidial rhachis, and a better-developed pygidial border furrow. All other species introduced by Rasetti (1963) to Elrathia do not belong to this genus, as is also the case with E. grazierensis Rasetti, 1965.

Elrathia kindlei Young and Ludvigsen, 1989 from the lowest part of the Cow Head Group of western Newfoundland has a pygidium similar to that typical for Eoptychoparia and is regarded herein as a representative of an as yet undescribed ptychoparioid genus.

Elrathia groenlandica n. sp. also resembles Elrathia? occidentalis (Walcott, 1884), described by Walcott (1884) from the Eldorado Limestone of Prospect Mountain, Nevada, as a species of Ptychoparia, transferred by Resser (1937a) to Elrathia Walcott, 1924, and best illustrated in Palmer (1954, pl. 17, fig. 15). Pygidia of this species are unknown to date, and the cranidium shows eye ridges unlike typical species of Elrathia so that its generic assignment remains open. It has been suggested that the species is better placed in Modocia (Robison, 1964). As explained by Palmer (1954), Walcott's type is crushed so that the nature of the glabellar furrows cannot be unequivocally determined. Differences to Elrathia groenlandica n. sp. are, in any case, the less-pronounced anterior border furrow in the cranidium, probably less obliquely directed palpebral lobes, and more steeply backward-directed S1 in Modocia? occidentalis.

Elrathia alabamensis Resser, 1938 and Elrathia georgiensis Resser, 1937b are each known only from a single specimen, which, although preserved as complete or nearly complete exoskeletons, are difficult to precisely evaluate. Both come from the Conasauga Formation. The type specimen of Elrathia georginensis from near Cave Spring, Georgia, was introduced as Ptychoparella georginensis and lacks librigenae and has long palpebral lobes and a large, almost semicircular pygidium (compare Fig. 4.3 herein and Resser, 1937b, pl. 8, fig. 44) that suggests affinities with Ehmaniella rather than Elrathia. However, its pygidium appears to be clearly differentiated from the typical pygidium of Ehmaniella. The type of Elrathia alabamensis from near Center, Alabama, 
shows characters typical for Elrathia, but has narrow fixigenae, and fine details of the pygidium are not visible (Resser, 1938, pl. 8, fig. 35). It is distinguished from E. groenlandica $\mathrm{n}$. sp. at least by a relatively longer (sag.) preglabellar field, a broader (tr.) frontal lobe with a shallow curvature, and palpebral lobes in a slightly moreposterior position.

The species described by Shaw (1957) as Chancia rasettii from the upper part of the Parker Slate of the St. Albans area, northwestern Vermont, has a slender glabella with a subtriangular front, palpebral lobes in a comparatively anterior position and a pygidium with five or even six rings in the pygidial rhachis, the latter almost reaching to the slightly indented posterior margin.

The median swelling in the anterior border furrow is a character seen in other ptychoparioid genera. It has been used by Sundberg (1994) to characterize Pseudoalokistocare Sundberg, 1994 from genera such as Altiocculus Sundberg, 1994, but seems to face the problem that the expression of this character varies strikingly between species. Pseudoalokistocare was reassigned to Alokistocare by Sundberg (1999) based on a cladistic analysis. Elrathia groenlandica n. sp. from the Ekspedition Bræ Formation shares a number of characters with Pseudoalokistocare/Alokistocare swasii from the Ehmaniella Biozone of the Swasey Limestone in the Drum Mountains, Utah. It is clearly distinguished, however, by its pygidium with a lenticular outline and the lower overall relief, smaller palpebral lobes, a much narrower border, and a slightly different configuration of the lateral glabellar furrows, and thus not regarded as closely related.

\section{Acknowledgements}

The material for this study was collected by J.S. Peel in 1979 during the North Greenland Project (1978-80) of the Geological Survey of Greenland.

Preparation of the material and the manuscript was made possible by research grant GE 549/21-1 to G.G. and by support from the Swedish Research Council (Vetenskapsrådet) to J.S.P. We thank E.B. Naimark (Moscow) for remarks on the manuscript and Peng Sh.Ch. (Nanjing) for details of the Chinese stratigraphy and localities. Thanks are due to R. Gozalo (Valencia) and F.A. Sundberg (Phoenix, AZ) for thoughtful reviews of the manuscript. J.-B. Caron (ROM, Toronto) provided the photos of Elrathina cordillerae specimens from the collections of the Royal Ontario Museum and photos of specimens from the University of Michigan Museum; D.J. Miller (University of Michigan Museum, Ann Arbor) kindly helped with information on the Rominger collection; and T.K. Baumiller gave permission to figure a specimen of Rominger's type lot of E. cordillerae from the University of Michigan Museum, Ann Arbor. The specimens from the USNM were photographed by M.R. Blaker.

\section{References}

Babcock, L.E., 1994, Systematics and phylogenetics of polymeroid trilobites from the Henson Gletscher and Kap Stanton formations (Middle Cambrian), North Greenland, in Peel, J.S., ed., Palaeontology, stratigraphy and environmental setting of Middle Cambrian outer shelf deposits: North Greenland, Bulletin Grønlands geologiske Undersøgelse, v. 169, p. 79-127.

Babcock, L.E., Robison, R.A., Rees, M.N., Peng, Sh., and Saltzman, M.R., 2007, The Global boundary Stratotype Section and Point (GSSP) of the Drumian Stage (Cambrian) in the Drum Mountains, Utah, USA:. Episodes, v. 30, p. 85-95.
Bird, J.M., and Rasetti, F., 1968, Lower, Middle, and Upper Cambrian faunas in the Taconic Sequence of eastern New York: stratigraphic and biostratigraphic significance: Geological Society of America, Regional Studies, Special Paper, v. 113, 66 p.

Blaker, M.R., and Peel, J.S., 1997, Lower Cambrian trilobites from North Greenland: Meddelelser om Grønland, Geoscience, v. 35, p. 1-145.

Campbell, K.S.W., 1975, The functional anatomy of phacopid trilobites: musculature and eyes: Royal Society of New South Wales, Journal and Proceedings, v. 108 , p. $168-188$.

Caron, J.B., and Jackson, D.A., 2006, Taphonomy of the greater Phyllopod Bed Community, Burgess Shale: Palaios, v. 21, p. 451-465.

Caron, J.B., and Jackson, D.A., 2008, Paleoecology of the Greater Phyllopod Bed community, Burgess Shale: Palaeogeography, Palaeoclimatology, Palaeoecology, v. 258, p. 222-256.

Chernysheva, N.E., ed., 1971, Amginskiy yarus Altae-Sayanskoy oblasti: Trudy Sibirskoy nauchno-issledovatel'skiy institut geologii, geofiziki i mineral'nogo syr'ya (SNIIGGiMS), Serya paleontologiya i stratigrafiya, 3. Zapadno-Sibirskoe nizhnoe izdatel'stvo, Novosibirsk, 267 p.

Clarkson, E.N.K., Ahlgren, J., and Taylor, C.M., 2003, Structure, ontogeny, and moulting of the olenid trilobite Ctenopyge (Eoctenopyge) angusta Westergård, 1922 from the upper Cambrian of Västergötland, Sweden: Palaeontology, v. 46, p. 1-27.

Conway Morris, S., 1979, The Burgess Shale (Middle Cambrian) fauna: Annual Review of Ecology and Systematics, v. 10, p. 327-349.

Deiss, C., 1939, Cambrian stratigraphy and trilobites of northwestern Montana: Geological Society of America, Special Papers, v. 18, 135 p.

Egorova, L.I., Shabanov, Yu.Ya., Pegel', T.V., Savitskiy, V.E., Sukhov, S.S., and Chernysheva, N.E., 1982, Mayskiy yarus stratotipicheskoy mestnosti (sredniy kembriy yugo-vostoko Sibirskoy platformy) [Type section of the Maya stage (Middle Cambrian of southeastern Siberian platform)]: Akademiya Nauk SSSR, Mezhvedomstvennyy Stratigraficheskiy komitet SSSR, Trudy, 8, Nauka, Moscow, 145 p.

Eldredge, N., 1971, Patterns of cephalic musculature in the Phacopina (Trilobita) and their phylogenetic significance: Journal of Paleontology, v. 45, p. 52-67.

Esteve, J., Sundberg, F.A., Zamora, S., and Gozalo, R., 2012, A new Alokistocaridae Resser, 1939 (Trilobita) from the middle Cambrian of Spain: Géobios, v. 45, p. 275-283.

Etheridge, R., Jr., 1902, Official contributions to the palaeontology of South Australia. No. 12-Evidence of further Cambrian trilobites: South Australian Parliamentary Paper, v. 51, p. 3-4.

Fletcher, T.P., and Collins, D.H., 2003, The Burgess Shale and associated Cambrian formations west of the Fossil Gully Fault Zone on Mount Stephen, British Columbia: Canadian Journal of Earth Sciences, v. 40, p. $1823-1838$.

Gaines, R.R., and Droser, M.L., 2003, Paleoecology of the familiar trilobite Elrathia kingii: an early exaerobic zone inhabitant: Geology, v. 31, p. $941-944$

Geyer, G., 1996, The Moroccan fallotaspidid trilobites revisited: Beringeria, v. 18 , p. $89-199$.

Geyer, G., and Peel, J.S., 2011, The Henson Gletscher Formation, North Greenland, and its bearing on the global Cambrian Series 2-Series 3 boundary: Bulletin of Geosciences, v. 86, p. 465-534.

Hartt, C.F., 1868, Fossils of the Primordial or Acadian Group at St John, in Dawson, J.W. Acadian Geology The Geological Structure, Organic Remains, and Mineral Resources of Nova Scotia, etc., 2nd ed.: London, Macmillan \& Co.,. p. 641-657.

Hawle, I., and Corda, A.J.C., 1847, Prodrom einer Monographie der böhmischen Trilobiten: Königlich böhmische Gesellschaft der Wissenschaften, Abhandlungen, v. 5, 176 p. (119-225-226-292).

Hicks, H., 1872, On some undescribed fossils from the Menevian Group, with a note on the Entomostraca by Prof. T. Rupert Jones: Quarterly Journal of the Geological Society, London, v. 28, p. 173-185.

Higgins, A.K., Ineson, J.R., Peel, J.S., Surlyk, F., and Sønderholm, M., 1991, Lower Palaeozoic Franklinian Basin of North Greenland: Bulletin Grønlands Geologiske Undersøgelse, v. 160, p. 71-139.

Ineson, J.R., and Peel, J.S., 1997, Cambrian shelf stratigraphy of North Greenland: Geology of Greenland Survey Bulletin, v. 173, 120 p.

Ineson, J.R., and Peel, J.S., 2011, Geological and depositional setting of the Sirius Passet Lagerstätte (early Cambrian), North Greenland: Canadian Journal of Earth Sciences, v. 48, p. 1259-1281.

Kobayashi, T., 1939, On the agnostids (Part I): Journal of the Faculty of Science, Imperial University Tokyo, sec. 2, v. 5, p. 62-198.

Laurie, J.R., 2004, Early Middle Cambrian trilobite faunas from NTGS Elkedra 3 corehole, southern Georgina Basin, Northern Territory: Memoirs of the Association of Australasian Paleontologists, v. 30, p. 221-260.

Lerosey-Aubril, R., Hegna, T.A., and Olive, S., 2011, Inferring internal anatomy from the trilobite exoskeleton: the relationship between frontal auxiliary impressions and the digestive system: Lethaia, v. 44, p. 166-184. 
Lu, Y.H., 1957, Trilobita, in Ku, Z.W., Yang, T.Y., Hsu, S.C., Yin, T.H., Yu, C.C., Chao, K.K., Lu, Y.H., and Hou, Y.T., Index Fossils of China, Invertebrata, Part 3: Beijing, Institute of Palaeontology, Academia Sinica, Geology Press, p. 249-294. [in Chinese]

Lu, Y.H., Chang, W.T., Chu, C.L., Chien, J.Y., and Hsiang, L.W., 1965, Trilobites of China. Pts. 1, 2: Beijing, Science Press, 766 p. [in Chinese]

Lu, Y.H., Chang, W.T., Chien, Y.Y., Chu, C.L., Lin, H.L., Zhou, Z.Y., Qian, Y., Zhang, S.G., and Yuan, J.L., 1974, Cambrian trilobites. in Nanjing Institute of Geology and Palaeontology, Academia Sinica ed., Handbook of Stratigraphy and Palaeontology of Southwest China: Beijing, Science Press, p. 82-107. [in Chinese with English summary]

Matthew, G.F., 1887, Illustrations of the fauna of the St. John Group. No. 4.On the smaller-eyed trilobites of Division I., with a few remarks on the species of the higher divisions of the group: Canadian Record of Science, v. 2 , p. $357-363$.

Matthew, G.F., 1899, Studies on Cambrian faunas, no. 3. Upper Cambrian fauna of Mount Stephen, British Columbia. The trilobites and worms: Transactions of the Royal Society of Canada, Series 2, v. 5, Sect. 4, p. 39-66.

McKee, E.D., and Resser, C.E., 1945, Cambrian history of the Grand Canyon region: Carnegie Institution Publications, v. 563, 232 p.

McLaughlin, K.P., and Enbysk, B.B., 1950, Middle Cambrian trilobites from Pend Oreille County, Washington: Journal of Paleontology, v. 24, p. 466-471.

Meek, F.B., 1870, Description of fossils collected by the U.S. Geological Survey, under the charge of Clarence King, esq.: Academy of Natural Sciences of Philadelphia Proceedings, v. 14, p. 54-64.

Naimark, E.B., 2012, Hundred species of the Genus Peronopsis Hawle et Corda, 1847: Paleontological Journal, v. 46, p. 945-1057. doi: 10.1134/ S003103011209001.

Öpik, A.A., 1979a, Middle Cambrian agnostids: systematics and biostratigraphy. Volume 1: Text: Bureau of Mineral Resources, Geology and Geophysics, Bulletin, v. 172, $188 \mathrm{p}$.

Öpik, A.A., 1979b, Middle Cambrian agnostids: systematics and biostratigraphy. Volume 2: Plates: Bureau of Mineral Resources, Geology and Geophysics, Bulletin, v. 172, 67 pls.

Palmer, A.R., 1954, An appraisal of the Great Basin Middle Cambrian trilobites described before 1900: United States Geological Survey, Professional Paper, v. 264-D, p. 55-86.

Palmer, A.R., 1968, Cambrian trilobites of east-central Alaska: United States Geological Survey Professional Paper, v. 559-B, 115 p.

Palmer, A.R., and Halley, R.B., 1979, Physical stratigraphy and trilobite biostratigraphy of the Carrara Formation (Lower and Middle Cambrian) in the southern Great Basin: U.S. Geological Survey Professional Paper, v. 1047, 131 p.

Palmer, A.R., and Peel, J.S., 1979, New Cambrian faunas from Peary Land, eastern North Greenland: Rapport Grønlands geologiske Undersøgelse, v. 91, p. $29-36$

Peel, J.S., ed., 1988, Stratigraphy and palaeontology of the Holm Dal Formation (late middle Cambrian), central North Greenland: Meddelelser om Grønland Geoscience, v. 20, 168 p.

Peel, J.S., ed., 1994, Palaeontology, stratigraphy and environmental setting of Middle Cambrian outer shelf deposits, North Greenland: Bulletin Grønlands Geologiske Undersøgelse, v. 169, 155 p.

Peel, J.S., and Ineson, J.R., 2011a, The Sirius Passet Lagerstätte (early Cambrian) of North Greenland: Palaeontographica Canadiana, v. 31, p. 109-118.

Peel, J.S., and Ineson, J.R., 2011b, The extent of the Sirius Passet Lagerstätte (early Cambrian) of North Greenland: Bulletin of Geosciences, v. 86, p. 535-543.

Peel, J.S., and Streng, M., 2015, A new middle Cambrian bradoriid arthropod from Greenland and western Canada: Journal of Paleontology, v. 89, p. 1-8.

Pei, F., 1991, The Cambrian of North China type in Henan Province: Regional Geology of China, v. 1991(3), p. 210-220.

Poulsen, C., 1927, The Cambrian, Ozarkian, and Canadian faunas of northwest Greenland: Meddelelser om Grønland, v. 70, p. 233-343.

Poulsen, C., 1958, Contributions to the palaeontology of the Lower Cambrian Wulff River Formation: Meddelelser om Grønland, v. 162, 25 p.

Poulsen, V., 1964, Contributions to the Lower and Middle Cambrian palaeontology and stratigraphy of northwest Greenland: Meddelelser om Grønland v. $164,105 \mathrm{p}$.

Rasetti, F., 1948, Middle Cambrian trilobites from the conglomerates of the Quebec (exclusive of the Ptychopariidea): Journal of Paleontology, v. 22, p. $45-52$.

Rasetti, F., 1951, Middle Cambrian stratigraphy and faunas of the Canadian Rocky Mountains: Smithsonian Miscellaneous Collections, v. 116 , p. 3-276.

Rasetti, F., 1955, Lower Cambrian ptychopariid trilobites from the conglomerates of Quebec: Smithsonian Miscellaneous Collections, v. 128, pt. 7, 35 p.

Rasetti, F., 1963, Middle Cambrian ptychoparioid trilobites from the conglomerates of Quebec: Journal of Paleontology, v. 37, p. 575-594.

Rasetti, F., 1965, Middle Cambrian trilobites of the Pleasant Hill Formation in central Pennsylvania: Journal of Paleontology, v. 39, p. 1007-1014.
Resser, C.E., 1936, Second contribution to nomenclature of Cambrian trilobites: Smithsonian Miscellaneous Collections, v. 85, p. 1-29.

Resser, C.E., 1937a, Third contribution to nomenclature of Cambrian trilobites: Smithsonian Miscellaneous Collections, v. 95, 29 p.

Resser, C.E., 1937b, Elkanah Billings' Lower Cambrian trilobites and associated species: Journal of Paleontology, v. 11, p. 43-54.

Resser, C.E., 1938, Cambrian System (restricted) of the Southern Appalachians: Geological Society of America Special Papers, v. 15, p. 1-140.

Resser, C.E. 1939, The Spence Shale and its fauna: Smithsonian Miscellaneous Collections, v. 97, p. 1-29.

Resser, C.E., and Endo, R., 1937, Description of the fossils, $n$ Endo, R., and Resser, C.E., The Sinian and Cambrian formations and fossils of southern Manchukuo: Manchurian Science Museum, Bulletin, v. 1, p. 103-301.

Robison, R.A., 1964, Middle Cambrian faunas from western Utah: Journal of Paleontology, v. 38, p. 79-92.

Robison, R.A., 1976, Middle Cambrian trilobite biostratigraphy of the Great Basin: Brigham Young University Geological Studies, v. 23, p. $93-109$.

Robison, R.A., 1988, Trilobites of the Holm Dal Formation (late Middle Cambrian), central North Greenland: Meddelelser om Grønland, Geoscience, v. 20, p. 23-103.

Robison, R.A., 1994, Agnostoid trilobites from the Henson Gletscher and Kap Stanton formations (Middle Cambrian), North Greenland: Bulletin Grønlands Geologiske Undersøgelse, v. 169, p. 25-77.

Robison, R.A., and Babcock, L.E., 2011, Systematics, paleobiology, and taphonomy of some exceptionally preserved trilobites from Cambrian Lagerstätten of Utah: Kansas University Paleontological Contributions, v. 5 , p. $1-47$.

Rominger, C., 1887, Description of primordial fossils from Mount Stephens, N. W. Territories of Canada: Proceedings of the Academy of Natural Sciences of Philadelphia, v. 1887, p. 12-19.

Rudolph, F., 1994, Die Trilobiten der mittelkambrischen Geschiebe. Systematik: Morphologie und Ökologie: Wankendorf, Verlag F. Rudolph, 309 p.

Schwimmer, D.R., 1973, The Middle Cambrian biostratigraphy of Montana and Wyoming [Ph.D. dissertation]: Stony Brook, New York, State University of New York, Stony Brook, 454 p.

Schwimmer, D.R., 1989, Taxonomy and biostratigraphic significance of some Middle Cambrian trilobites from the Conasauga Formation in western Georgia: Journal of Paleontology, v. 63, p. 484-494.

Shaw, A.B., 1957, Paleontology of Northwestern Vermont. 6. The early Middle Cambrian fauna: Journal of Paleontology, v. 31, p. 785-792.

Shergold, J.H., and Laurie, J.R., 1997, Introduction to the Suborder Agnostina, in Kaesler, R.L., ed., Treatise on Invertebrate Paleontology, Part O, Arthropoda 1. Trilobita, Revised. Volume 1: Introduction, Order Agnostida, Order Redlichiida: Boulder, Colorado and Lawrence, Kansas, Geological Society of America and University of Kansas Press, p. 331-383.

Solov'ev, I.A., and Grikurov, G.E., 1978, Pervye nakhodki srednekembriyskikh trilobitov v khrebte Sheklton (Antarktika) (First findings of Middle Cambrian trilobites in the Shackleton Range (Antarctica)): Doklady komissii Antarktiki, v. 17, p. 187-198.

Sundberg, F.A., 1994, Corynexochida and Ptychopariida (Trilobita,Arthropoda) of the Ehmaniella Biozone (Middle Cambrian), Utah and Nevada: Contributions in Science, Natural History Museum of Los Angeles County, v. $446,137 \mathrm{p}$.

Sundberg, F.A., 1999, Redescription of Alokistocare subcoronatum (Hall and Whitfield, 1877), the type species of Alokistocare, and the status of Alokistocaridae, Resser, 1938b (Ptychopariida: Trilobita, Middle Cambrian): Journal of Paleontology, v. 73, p. 1126-1143.

Sundberg, F.A., 2004, Cladistic analysis of Early-Middle Cambrian kochaspid trilobites (Ptychopariida): Journal of Paleontology, v. 78, p. 920-940.

Sundberg, F.A., 2007, Nightmare on Resser Street-Dealing with Resser's trilobite taxonomy, in Mikulic, D.G., Landing, E., and Kluessendorf, J., eds., Fabulous Fossils-300 Years of Worldwide Research on Trilobites: Albany, New York, New York State Education Department, p. 213-224.

Surlyk, F., and Ineson, J.R., 1987, Aspects of Franklinian shelf, slope and trough evolution and stratigraphy in North Greenland: Rapport, Grønlands geologiske Undersøgelse, v. 133, p. 41-58.

Swinnerton, H.H., 1915, Suggestions for a revised classification of trilobites: Geological Magazine, Series 6, v. 2, p. 487-496, 538-545.

Walcott, C.D., 1884, On the Cambrian faunas of North America Preliminary studies: Bulletin of the U.S. Geological Survey, v. 2(10), p. $1-72$ (285-352).

Walcott, C.D., 1888, Cambrian fossils from Mount Stephen, North-West Territory of Canada: American Journal of Science, Series 3, v. 36, p. 161-167.

Walcott, C.D., 1908, Mount Stephen rocks and fossils: Canadian Alpine Journal, v. 1 , p. $232-249$.

Walcott, C.D., 1912, Cambrian Geology and Paleontology, 2, no. 6. Middle Cambrian Branchiopoda, Malacostraca, Trilobita and Merostomata: Smithsonian Miscellaneous Collections, v. 57, p. 145-228. 
Walcott, C.D., 1918, Cambrian Geology and Paleontology, 4, no. 4. Appendages of trilobites: Smithsonian Miscellaneous Collections, v. 67, p. $115-216$.

Walcott, C.D., 1924, Cambrian Geology and Paleontology, 5, no. 2. Cambrian and Lower Ozarkian trilobites: Smithsonian Miscellaneous Collections, v. 75 , p. $51-60$.

Westergård, A.H., 1936, Paradoxides xlandicus Beds of Öland with the account of a diamond boring through the Cambrian at Mössberga: Sveriges Geologiska Undersökning, v. 30, p. 1-66.

Westergård, A.H., 1946, Agnostidea of the Middle Cambrian of Sweden: Sveriges Geologiska Undersökning, Avhandlingar och uppsatser, Series C477, Årsbok 40, 140 p.

Westrop, S.R., Ludvigsen, R., and Kindle, C.H., 1996, Marjuman (Cambrian) Trilobites of the Cow Head Group, Western Newfoundland: Journal of Paleontology, v. 70, p. 804-829.

White, C.A., 1874, Preliminary report upon invertebrate fossils collected by the expeditions of 1871, 1872, and 1873, with descriptions of of new species: Report of the United States Army Geographical and Geological Exploratory Surveys West of the 100th Meridian (Wheeler), pamphlet, $27 \mathrm{p}$.

Whitehouse, F.W., 1936, The Cambrian faunas of north-eastern Australia: Memoirs of the Queensland Museum, v. 11, parts 1-2, p. 3-114.

Woodward, H., 1902, The Canadian Rockies. Pt. 1-On a collection of Middle Cambrian fossils obtained by Edward Whymper, Esq., F. R. G. S., from
Mount Stephen, British Columbia: Geological Magazine, Series 4, v. 9, p. 502-505, 529-544.

Young, G.A., and Ludvigsen, R., 1989, Mid-Cambrian trilobites from the lowest part of the Cow Head Group, Western Newfoundland: Geological Survey of Canada, Bulletin, v. 392, 49 p.

Zhang, W.T., Lu, Y.H., Zhu, Z.L., Qian, Y.Y., Lin, H.L., Zhou, Z., Zhang, S., and Yuan, J.L., 1980, Cambrian trilobite faunas of southwestern China: Palaeontologia Sinica, new series B, v. 16, p. 1-497.

Zhao, Y.L., Yuan, J.L., McCollum, L., Sundberg, F.A., Yang, R.D., Guo, Q.J., Zhu, L.J., and Yang, X.L., 2001, A potential GSSP for the Lower and Middle Cambrian boundary near Balang village, Taijiang County, Guizhou Province, China, in Zhu, M.Y., Van Iten, H., Peng, S.C., and Li, G.X., eds., The Cambrian of South China: Acta Palaeontologica Sinica, v. 40 (Suppl.), p. 130-142.

Zhao, Y.L., Zhu, M.Y., Babcock, L.E., and Peng, J., eds., 2011, The Kaili Biota: Marine Organisms from 508 Million Years Ago: Guizhou, China, Guizhou Publishing Group, $251 \mathrm{p}$. [in Chinese]

Zhou, Z.Y., and Dean, W.T., eds., 1996, Phanerozoic Geology of Northwest China: Beijing, Science Press, 316 p.

Accepted 25 November 2014 